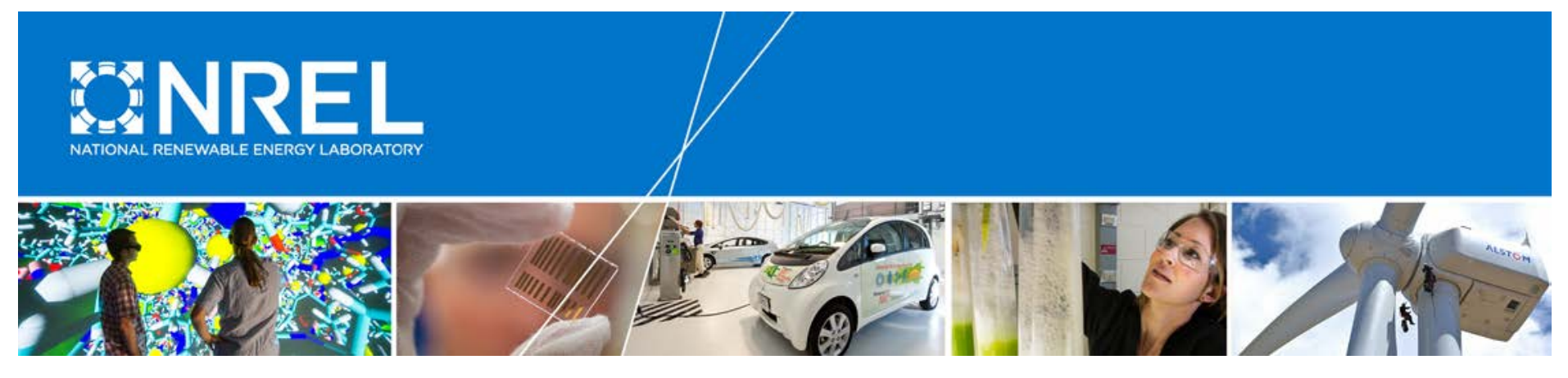

\title{
Evolving Distributed Generation Support Mechanisms: Case Studies from United States, Germany, United Kingdom, and Australia
}

Travis Lowder, Ella Zhou, and Tian Tian National Renewable Energy Laboratory

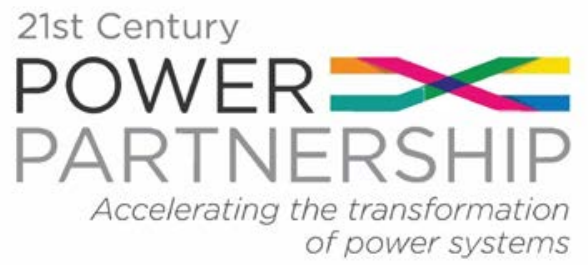

NREL is a national laboratory of the U.S. Department of Energy Office of Energy Efficiency \& Renewable Energy Operated by the Alliance for Sustainable Energy, LLC

This report is available at no cost from the National Renewable Energy Laboratory (NREL) at www.nrel.gov/publications.

Technical Report

NREL/TP-6A20-67613

March 2017

Contract No. DE-AC36-08GO28308 
Evolving Distributed Generation Support Mechanisms: Case Studies from United States, Germany, United Kingdom, and Australia

Travis Lowder, Ella Zhou, and Tian Tian National Renewable Energy Laboratory

Prepared under Task No. ACTC.1340

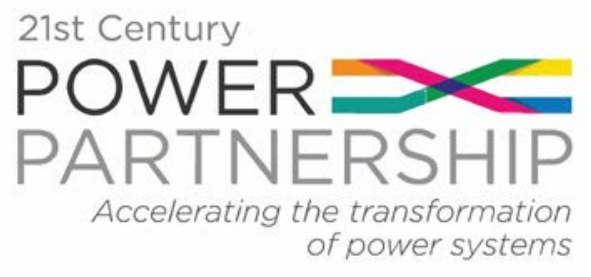

NREL is a national laboratory of the U.S. Department of Energy Office of Energy Efficiency \& Renewable Energy Operated by the Alliance for Sustainable Energy, LLC

This report is available at no cost from the National Renewable Energy Laboratory (NREL) at www.nrel.gov/publications.

National Renewable Energy Laboratory 15013 Denver West Parkway Golden, CO 80401

303-275-3000 • www.nrel.gov

\section{Technical Report}

NREL/TP-6A20-67613

March 2017

Contract No. DE-AC36-08G028308 


\title{
NOTICE
}

This report was prepared as an account of work sponsored by an agency of the United States government. Neither the United States government nor any agency thereof, nor any of their employees, makes any warranty, express or implied, or assumes any legal liability or responsibility for the accuracy, completeness, or usefulness of any information, apparatus, product, or process disclosed, or represents that its use would not infringe privately owned rights. Reference herein to any specific commercial product, process, or service by trade name, trademark, manufacturer, or otherwise does not necessarily constitute or imply its endorsement, recommendation, or favoring by the United States government or any agency thereof. The views and opinions of authors expressed herein do not necessarily state or reflect those of the United States government or any agency thereof.

This report is available at no cost from the National Renewable Energy Laboratory (NREL) at www.nrel.gov/publications.

Available electronically at SciTech Connect http:/www.osti.gov/scitech

Available for a processing fee to U.S. Department of Energy and its contractors, in paper, from:

\author{
U.S. Department of Energy \\ Office of Scientific and Technical Information \\ P.O. Box 62 \\ Oak Ridge, TN 37831-0062 \\ OSTI http://www.osti.gov \\ Phone: 865.576.8401 \\ Fax: 865.576.5728 \\ Email: reports@osti.gov
}

Available for sale to the public, in paper, from:

\author{
U.S. Department of Commerce \\ National Technical Information Service \\ 5301 Shawnee Road \\ Alexandria, VA 22312 \\ NTIS http://www.ntis.gov \\ Phone: 800.553 .6847 or 703.605 .6000 \\ Fax: 703.605.6900 \\ Email: orders@ntis.gov
}




\section{Acknowledgments}

This report is a part of the Boosting Renewable Energy as Part of China's Energy Revolution program, a five-year multilateral effort supported by the Children's Investment Fund Foundation in the United Kingdom. The program includes a series of technical collaborations between the National Renewable Energy Laboratory (NREL), $21^{\text {st }}$ Century Power Partnership, China National Renewable Energy Center (CNREC), Danish Energy Agency, Deutsche Gesellschaft für Internationale Zusammenarbeit (GIZ), and other key research institutes and energy experts in China, the United States, Denmark, and Germany.

The authors would like to thank the following individuals for their inputs to and review of this report: Markus Steigenberger and Fabian Joas from Agora Energiewende; Peter Olmsted from the New York State Department of Public Service, and John Joshi from the New York State Energy Research and Development Authority. Additionally, the authors wish to acknowledge their NREL colleagues for providing critical feedback, including Douglas Arent, John Barnett, David Mooney, Jeffrey Logan, Eric O’Shaughnessy, Paul Schwabe, and Owen Zinaman. 


\section{Acronyms}

\begin{tabular}{|c|c|}
\hline $\mathrm{AB}$ & Assembly Bill (California, United States) \\
\hline APS & Arizona Public Service \\
\hline $\mathrm{CfD}$ & contracts for difference \\
\hline CHP & combined heat and power \\
\hline CPUC & California Public Utilities Commission \\
\hline DG & distributed generation \\
\hline DGPV & distributed generation photovoltaics \\
\hline DNO & distribution network operator \\
\hline DR & demand response \\
\hline DRAM & demand response auction mechanism \\
\hline DSP & distributed system platform \\
\hline EEG & $\begin{array}{l}\text { Erneuerbare Energien Gesetz (Renewable } \\
\text { Energy Sources Act, Germany) }\end{array}$ \\
\hline $\mathrm{EV}$ & electric vehicle \\
\hline FiT & feed-in tariff \\
\hline FiP & feed-in premium \\
\hline GW & gigawatt \\
\hline IOU & investor-owned utility \\
\hline NEM & net energy metering \\
\hline NREL & National Renewable Energy Laboratory \\
\hline Ofgem & Office of Gas and Electricity Markets (U.K.) \\
\hline $\mathrm{REC}(\mathrm{s})$ & renewable energy certificate(s) \\
\hline RET & renewable energy target (Australia) \\
\hline REV & $\begin{array}{l}\text { Reforming the Energy Vision (New York, } \\
\text { United States) }\end{array}$ \\
\hline $\mathrm{RO}$ & renewable obligation (U.K.) \\
\hline $\mathrm{ROC}$ & renewable obligation certificate (U.K.) \\
\hline SGIP & $\begin{array}{l}\text { Self-Generation Incentive Program } \\
\text { (California, United States) }\end{array}$ \\
\hline STC & $\begin{array}{l}\text { small-scale technology certificate } \\
\text { (Australia) }\end{array}$ \\
\hline TOU & time-of-use \\
\hline TWh & terawatt-hours \\
\hline Wh & watt-hour \\
\hline
\end{tabular}




\section{Table of Contents}

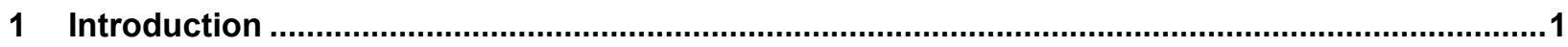

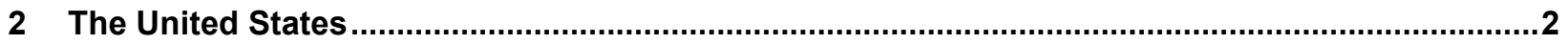

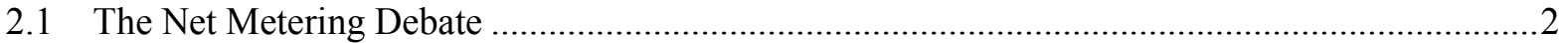

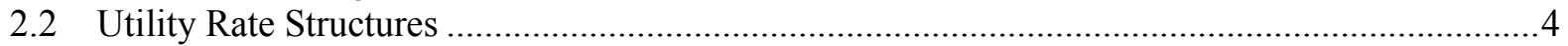

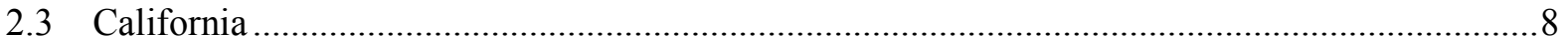

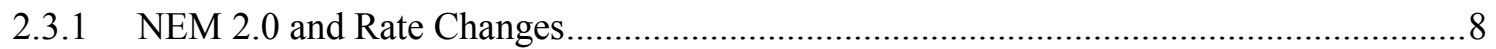

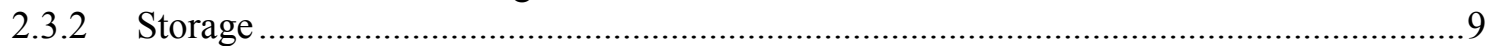

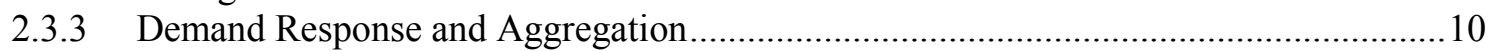

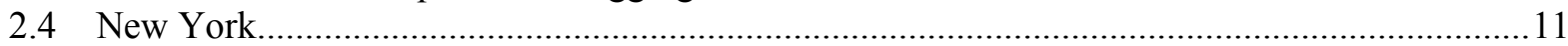

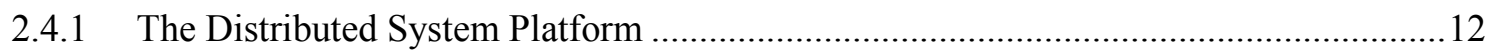

2.4.2 Utility Business Models and Ratemaking ............................................................ 14

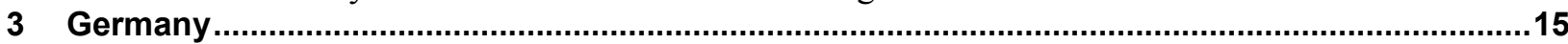

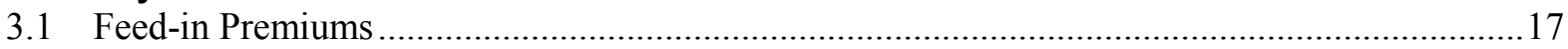

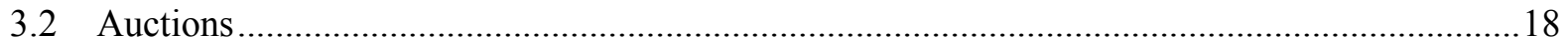

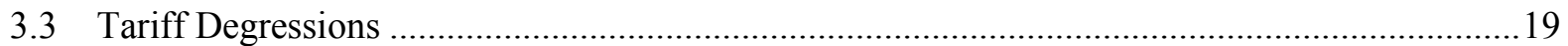

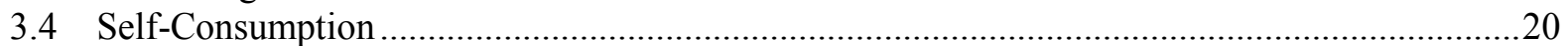

3.5 Other Distributed Generation Support Mechanisms ............................................................20

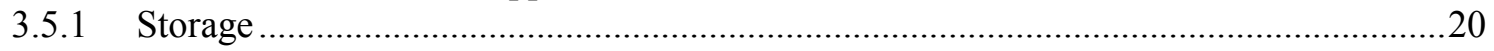

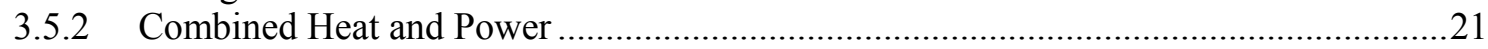

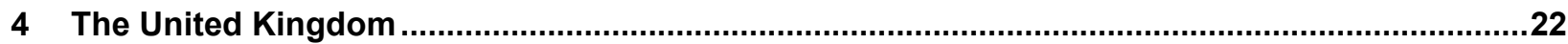

4.1 Distributed Generation: Development Status and Future Projections ......................................22

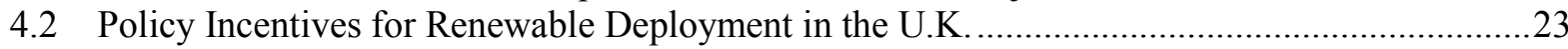

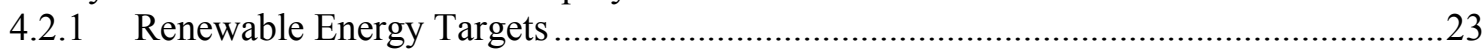

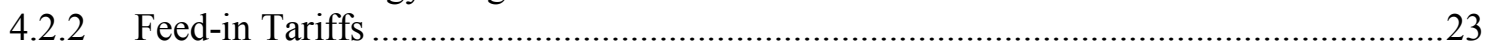

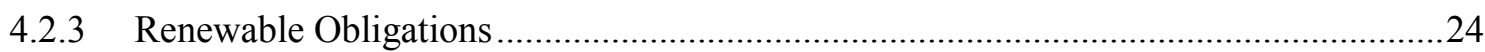

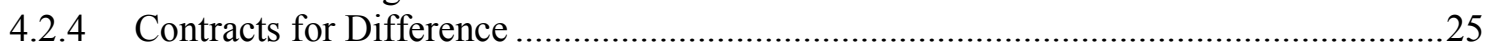

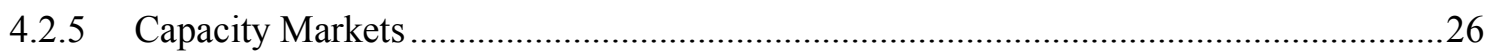

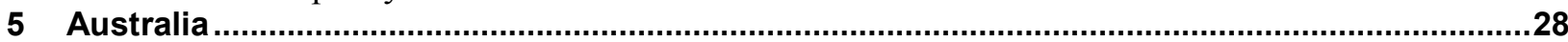

5.1 Distributed Generation: Development Status and Projections.................................................28

5.2 National Programs: Rebates and Renewable Energy Targets.................................................29

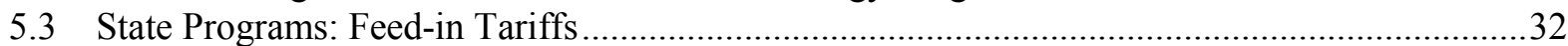

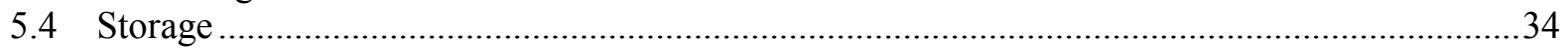

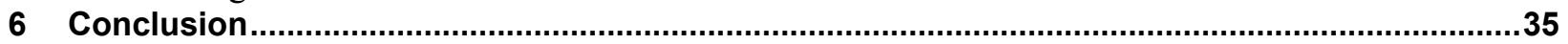

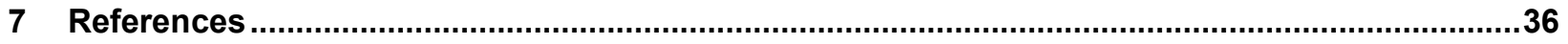




\section{List of Figures}

Figure 1. Makeup of Germany's 2014 EEG surcharge (left) and 2014 retail electricity price (right)..........16

Figure 2. Annual and cumulative installed PV capacity in Germany, 2001-2015...............................17

Figure 3. Annual DG installations in the U.K. by technology (MW) ................................................22

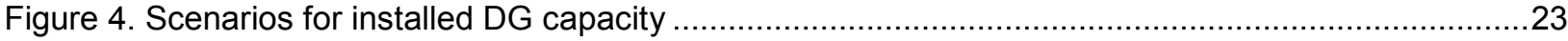

Figure 5. Quarterly installed capacity under FiT by technology type (MW) .......................................24

Figure 6. Australia renewable energy generation by technology in 2015 (percentage of total

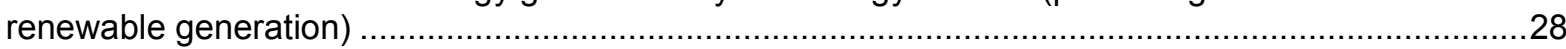

Figure 7. Annual and cumulative installed DGPV capacity in Australia, 2001-2015 ...........................31

Figure 8. Summary of national level renewable energy policy in Australia .............................................31

\section{List of Tables}

Table 1. Proposed and Active Changes to DGPV Customer Compensation and Utility Bills .....................5

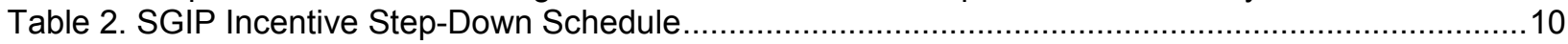

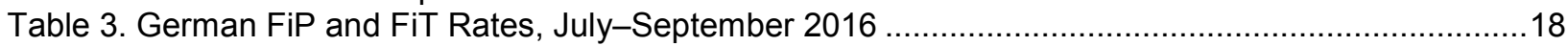

Table 4. Germany PV Auctions for Large-Scale Ground-Mount, 2015-2016 .....................................18

Table 5. German Tariff Degressions by Capacity Corridor ............................................................... 19

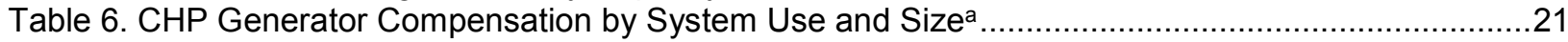

Table 7. Scheduled Solar Credit Multiplier Step-down Schedule.......................................................30

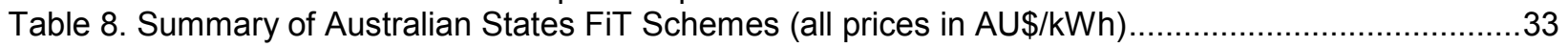




\section{Introduction}

This report expands on a previous National Renewable Energy Laboratory (NREL) technical report (Lowder et al. 2015) that focused on the United States' unique approach to distributed generation photovoltaics (DGPV) support policies and business models. While the focus of that report was largely historical (i.e., detailing the policies and market developments that led to the growth of DGPV in the United States), this report looks forward, narrating recent changes to laws and regulations as well as the ongoing dialogues over how to incorporate distributed generation (DG) resources onto the electric grid. This report also broadens the scope of Lowder et al. (2015) to include additional countries and technologies. DGPV and storage are the principal technologies under consideration (owing to market readiness and deployment volumes), but the report also contemplates any generation resource that is (1) on the customer side of the meter, (2) used to, at least partly, offset a host's energy consumption, and/or (3) potentially available to provide grid support (e.g., through peak shaving and load shifting, ancillary services, and other means). ${ }^{1}$

DGPV, because it represents the majority of deployed DG in the market today, can be considered a bellwether for the other technologies. That is, it has largely precipitated the legal, policy, and regulatory dialogues that may serve as foundational to the ways in which other DG resources will be incorporated onto the grid going forward. Accordingly, this report focuses principally on how countries are rethinking DGPV support, though it also indicates — where applicable — how the policy, regulatory, and market environments are reorganizing in anticipation of further DG penetration.

This report presents a series of case studies of how several countries are pivoting away from their historical forms of support for DGPV toward more market-based schemes. Where relevant, it also discusses how these countries are attempting to incentivize supplemental DG technologies such as storage and combined heat and power (CHP). The countries presented - the United States, Germany, the United Kingdom, and Australiawere selected because they host a sizable DGPV capacity (relative to the rest of the world) and they currently have a dynamic policy, regulatory, and market environment. Germany, the U.K., and Australia have all employed a feed-in tariff (FiT) to serve as the principal engine of DGPV growth, but each has chosen a distinct path to transition past this policy. The United States - unique among nations for having achieved renewables growth without the aid of a national FiT - is a study in how the economics of DG for consumers is becoming contingent on the value these technologies can provide to the grid.

\footnotetext{
${ }^{1}$ Definitions of what constitutes a DG technology vary, but this report generally considers battery storage, electric vehicle charging, combined heat and power generators, as well as other, less common forms of DG (e.g., micro wind turbines and fuel cells) to be DG technology. Demand response- though neither a generator nor a technology in and of itself-is discussed in Section 2.3.3.
} 


\section{The United States}

The success of DGPV in the United States has sparked a national conversation about how to value DG resources and what kind of regulatory and compensatory frameworks can accommodate an increasingly decentralized, distributed grid. At present, this conversation is manifesting in debates over net energy metering (NEM) regulations, utility rate design, and DG valuation, with each of these debates occurring on a state-bystate basis. Thus, while DGPV has had the benefit of maturing in an environment with fairly consistent NEM laws and utility rate structure ${ }^{2}$ across states, it appears that, going forward, it and other DG technologies will likely not enjoy this uniformity, at least in the near-term.

\subsection{The Net Metering Debate}

The development of the DGPV portfolio in the United States is a function of various policies and innovations, including federal tax benefits, state incentives, and novel business and financing models (e.g., third-party ownership and property assessed clean energy), and NEM (Lowder et al. 2015). While the former three conditions have affected the cost of and consumer value proposition in adopting rooftop solar, NEM laws have been especially critical in rendering the economic performance of DGPV competitive with other home or business investments.

In an environment where no "must-take" contracts are available on a national-scale (i.e., as there are with FiTs), NEM has allowed DGPV hosts to export any unused solar energy onto the grid and receive credits for that generation (per kilowatt-hour $[\mathrm{kWh}]$ ) against their utility bills. Forty-one U.S. states (as well as the District of Columbia and several U.S. territories) have net metering laws, many of which provide for compensation at the full retail rate - that is, excess generation is counted as a 1:1 offset against the volumetric electricity rate, inclusive of all adders, riders, taxes, and other attendant charges.

Full-retail-rate NEM can be an essential mechanism for DGPV hosts to achieve favorable economics on their investment because it diminishes the importance of the coincidence of solar generation and load from the host in determining payback. NEM allows for energy export to the grid at any time a host's solar generation exceeds the host's use, and these exports offset electricity consumed by the host at a different time during the same billing cycle at the same price level (Shah 2014). Changes to NEM laws (e.g., the implementation of net billing, which decouples the rate at which generators are compensated from the retail electricity rate) may impact DGPV hosts' payback times,

\footnotetext{
${ }^{2}$ That is, the predominance of the volumetric rate as the principal charge on customers' electric bills
} 
and, in some cases, extend them. ${ }^{3}$ This could dampen DGPV's marketability to homeowners and businesses in the absence of economical storage solutions, and slow deployment.

Recently, NEM has come under fire from utilities, regulators, and policymakers as providing an unintended "cross-subsidy" - a framework that allegedly rewards solar customers at the expense of non-solar customers in the utilities service territory. NEM allows most solar customers to pay lower electricity bills by offsetting their usage and therefore their volumetric charges. This leaves utilities with a potentially shrinking usage base from which to recoup their fixed costs (e.g., the costs associated with financing and maintaining the transmission and distribution infrastructure). Therefore, as the argument goes, infrastructure maintenance costs fall disproportionately on non-solar customers. This is one of the motivations for raising fixed charges on customer bills and/or implementing a minimum bill requirement on DGPV customers. See Table 1 (page 5) for more information on these strategies.

Across the United States, utility regulatory bodies are opening dockets to address this cross-subsidy issue, policymakers are bringing legislation to vote, and stakeholders on both sides remain actively engaged in the debate. According to the North Carolina Clean Energy Technology Center, 42 states and the District of Columbia took some sort of action on NEM, rate design, and/or solar ownership in the second quarter of 2016 (Proudlove et al. 2016). These actions include (1) cutting generator compensation rates (i.e., transitioning to a "net-billing" scheme-see Table 1), (2) mandating higher fixed charges or other mandatory charges for grid maintenance that cannot be offset by excess generation (such as non-bypassable charges and minimum bills - see Table 1), (3) restructuring rates to time-of-use (TOU) or other time-varying regimes, and (4), in one case, transitioning to a self-supply tariff (Hawaii).

In a case that is unique as of this writing, the state of Minnesota has implemented a "value of solar tariff," which is currently optional for utilities (i.e., they can choose to offer either the NEM retail rate or the value of solar tariff as the means of compensation for PV generators). As of the beginning of 2015, 30 states have conducted DG valuation studies, though none has — on a statewide basis - implemented a tariff structure as has Minnesota. The City of Austin, Texas also has also adopted a local (i.e. non-statewide) value of solar tariff.

\footnotetext{
${ }^{3}$ The precise effect on payback periods will depend on several factors under a given NEM regime and utility rate structure. Importantly, for time-varying rates, the respective periods of peak pricing and peak solar generation are critical in determining payback. For example, if a DGPV host's peak generation were largely coincident with the grid system peak and that host's peak load were later in the day, the solar generation would be credited at a higher rate than the bulk of the host's consumption charges. Provided this spread remained consistent over an extended period, this scenario would accelerate payback of the DGPV system relative to a full-retail-rate NEM scheme under a flat rate structure. The implementation of timevarying rates can influence hosts to better manage their energy consumption so as to effect a situation such as this. However, it could be possible that a significant quantity of DGPV on the grid could in fact push the peak system load (and thus prices) to later in the day after the sun begins to set, thus eroding DGPV economics (Darghouth et al. 2015).
} 
The methodologies and compensation levels behind solar valuation are still evolving in the United States, and perspectives differ among stakeholders. DGPV advocates argue solar provides more benefits to the grid than just energy, including the deferral of upgrades to transmission and distribution infrastructure, and the reduction of peak demand (SEIA 2016). Several studies supporting this standpoint have quantified that the cost shift from solar to non-solar customers implicit in NEM is more than offset by these benefits (SEIA 2016; RMI 2013). However, others do not ascribe as much value to this offset (NARUC 2016; RMI 2013).

\subsection{Utility Rate Structures}

Accompanying the NEM discussion have been several others on utility rate restructuring. Aside from the decoupling of a handful of utilities and the unconventional structures of some municipal and cooperative utilities, large investor-owned utilities (IOUs) have predominantly adhered to the cost-of-service model for nearly a century and residential tariff structures have changed little over that time. Customer bills in IOU service territories consist primarily of a flat per-kilowatt-hour volumetric charge. Fixed charges (which do not change with the level of use) comprise a smaller portion of customer bills (NARUC 2016). ${ }^{4}$ With increasing penetrations of DG resources, there may be attrition to the revenue streams necessary for utilities to recoup their investment in fixed assets while meeting the regulated rate of return for their shareholders.

Several utilities contend that fixed costs are a significant part of their cost portfolio in the near term and therefore should be given more weight on customers' bills, especially for DG customers who can reduce their contribution to these costs through NEM (NARUC 2016). Other means of ensuring that DGPV customers pay for a portion of grid infrastructure include minimum bills, standby charges, and grid access fees.

Additionally, utilities and regulators are considering migrating DGPV customers to TOU rates, which will value the DGPV's exported generation as a function of the time it was generated (e.g., higher at peak load hours and lower at the shoulders of the day). TOU rates would also base customers' volumetric charge on the time of day that the energy is consumed. California's "NEM 2.0" successor tariff (see Section 2.3.1) mandates that all DGPV customers migrate to TOU, as does a recent pilot compromise between the Colorado solar industry and the local utility, Xcel Energy. While utilities and regulators are increasingly looking to TOU rates as a key component in the transition to follow-on NEM schemes, it is important to note that most of these plans apply only to customers who host on-site generation. For the rest of the customer base, the more traditional flat or block volumetric rates will still apply. As of today, no IOUs mandate TOU rates across an entire customer base.

\footnotetext{
${ }^{4}$ Commercial tariffs differ in that they typically feature a demand charge- a charge per kilowatt of the highest period of usage in a 10-minute to a 30-minute window each month - and may rely on TOU pricing for the volumetric charge. Commercial volumetric rates in the United States are generally lower than those in the residential sector, and demand charges often serve as the largest portion of the bill.
} 
Table 1 summarizes pending and actual changes to U.S. NEM laws as well as various rate reforms under discussion. The table is not intended to be comprehensive, but rather it provides an overview of the transitional options across states. In parallel with the discussions of NEM and rate reform is one about the ideal design and regulation of utilities in a DG-heavy power system. Myriad proposals have been advanced by stakeholders on all sides of the issue, from smaller regulatory measures such as price caps and performance incentives to the kind of broad-based restructuring evidenced in New York's Reforming the Energy Vision (REV) initiative.

Table 1. Proposed and Active Changes to DGPV Customer Compensation and Utility Bills

\begin{tabular}{|c|c|c|}
\hline Proposed/Active Change & Description & Notes \\
\hline Net Billing & $\begin{array}{l}\text { Compensation for excess } \\
\text { generation from an on-site } \\
\text { generator at a rate other than the } \\
\text { retail rate-when the } \\
\text { compensation rate is lower than } \\
\text { the retail rate, it is more valuable } \\
\text { for hosts to offset load than it is to } \\
\text { export to the grid. Metering is not } \\
\text { bidirectional, as is the case with } \\
\text { NEM (i.e., when the generator is } \\
\text { exporting to the grid, the host's } \\
\text { meter does not spin backward). In } \\
\text { some cases, proposed net billing } \\
\text { rates may be pegged to an } \\
\text { indicator, such as the local utility's } \\
\text { avoided cost. }\end{array}$ & $\begin{array}{l}\text { Nevada has adopted a } \\
\text { schedule of reductions for } \\
\text { exported generation for } \\
\text { customers who have installed } \\
\text { solar after December 15, } 2015 \text {. } \\
\text { Hawaii has replaced its NEM } \\
\text { program with a successor } \\
\text { regime that offers reduced } \\
\text { compensation for exported } \\
\text { generation, though this } \\
\text { program has reached capacity } \\
\text { as of this writing. } \\
\text { Massachusetts has a reduced } \\
\text { PV compensation rate for } \\
\text { commercial systems. Arizona, } \\
\text { Maine, New Hampshire, and } \\
\text { other states have also had } \\
\text { regulatory and legislative } \\
\text { activity related to net billing or } \\
\text { reduced compensation. }\end{array}$ \\
\hline Fixed Charge Increase & $\begin{array}{l}\text { An additional charge on DG } \\
\text { customers' utility bills is meant to } \\
\text { ensure that these customers } \\
\text { contribute to the utility's cost of } \\
\text { maintaining grid infrastructure. } \\
\text { Fixed charges can come in the } \\
\text { form of a flat fee, or they can be } \\
\text { determined on the basis of hosts' } \\
\text { DG kW capacity. Fixed charges } \\
\text { that apply only to DGPV } \\
\text { customers are sometimes } \\
\text { referred to as "standby charges." }\end{array}$ & $\begin{array}{l}\text { As of the second quarter of } \\
2016,42 \text { utilities in } 25 \text { states } \\
\text { and the District of Columbia } \\
\text { had proposed increasing } \\
\text { residential fixed charges by at } \\
\text { least } 10 \% \text {; the median } \\
\text { percentage increase was } 50 \% \text {. } \\
\text { In the utility rate cases decided } \\
\text { in the third quarter of } 2016 \text {, } \\
\text { state regulators approved fixed } \\
\text { charge increases ranging from } \\
4 \% \text { over existing fixed charges } \\
\text { to } 73 \% \text {; the median increase } \\
\text { was } 26 \% \text {. }\end{array}$ \\
\hline
\end{tabular}




\begin{tabular}{|c|c|c|}
\hline Proposed/Active Change & Description & Notes \\
\hline $\begin{array}{l}\text { Non-Bypassable } \\
\text { Charges }\end{array}$ & $\begin{array}{l}\text { In a NEM arrangement, non- } \\
\text { bypassable charges cannot be } \\
\text { offset by energy exported to the } \\
\text { grid; thus, they act as a de facto } \\
\text { reduction to the NEM } \\
\text { compensation rate. }\end{array}$ & $\begin{array}{l}\text { California is currently the only } \\
\text { state that has included non- } \\
\text { bypassable charges in its NEM } \\
\text { compensation scheme. The } \\
\text { charges include a Public } \\
\text { Purpose Program Charge, a } \\
\text { Nuclear Decommissioning } \\
\text { Charge, a Competition } \\
\text { Transition Charge, and } \\
\text { Department of Water } \\
\text { Resources Bond Charges. }\end{array}$ \\
\hline Minimum Bill & $\begin{array}{l}\text { Mandates that DG customers pay } \\
\text { at least a certain amount per } \\
\text { month, thus preventing them from } \\
\text { ever reducing their utility bills to } \\
\$ 0 \text { if their system produces more } \\
\text { energy than they consume-- } \\
\text { a minimum bill does not change } \\
\text { the rate charges of the bill; thus, } \\
\text { it only applies to those customers } \\
\text { who would offset their energy use } \\
\text { with DG resources. Moreover, } \\
\text { unlike a fixed charge (which is } \\
\text { applied to every bill regardless of } \\
\text { the offset level), a minimum bill is } \\
\text { only applied if a customer's } \\
\text { charges fall below a certain } \\
\text { threshold. }\end{array}$ & $\begin{array}{l}\text { Minimum bills may only } \\
\text { marginally affect solar } \\
\text { customers, while increased } \\
\text { fixed charges-because they } \\
\text { are additional to any costs a } \\
\text { solar customer would pay and } \\
\text { they are not a mere floor } \\
\text { mechanism-would impose } \\
\text { greater costs. Minimum bill } \\
\text { implementations can be found } \\
\text { in California, Hawaii (as part of } \\
\text { the customer-self supply } \\
\text { scheme-see the Customer } \\
\text { Self-Supply section below in } \\
\text { this table), and Massachusetts. }\end{array}$ \\
\hline Time-Varying Rates & $\begin{array}{l}\text { For volumetric rates, the charge } \\
\text { per kilowatt-hour varies } \\
\text { depending on the time of day that } \\
\text { the energy is consumed. These } \\
\text { rate structures are intended to } \\
\text { more accurately reflect the utility's } \\
\text { cost in serving load and to send } \\
\text { economic signals encouraging } \\
\text { conservation at times of high } \\
\text { electricity prices (reducing } \\
\text { demand and thus prices). Time- } \\
\text { varying rates include TOU, } \\
\text { variable peak pricing, and critical } \\
\text { peak pricing. }\end{array}$ & $\begin{array}{l}\text { California has mandated that } \\
\text { all customers enrolled in its } \\
\text { NEM } 2.0 \text { plan will be subject to } \\
\text { TOU rates. Additionally, } \\
\text { Colorado has a two-year pilot } \\
\text { program that will transition } \\
\text { solar customers to TOU. } \\
\text { Several other states are } \\
\text { discussing mandatory } \\
\text { implementation for DG } \\
\text { customers going forward. Many } \\
\text { other utilities around the United } \\
\text { States offer voluntary TOU rate } \\
\text { plans, but, as of this writing, } \\
\text { there are no mandatory TOU } \\
\text { rates for all customers within } \\
\text { any IOU's service territory. }\end{array}$ \\
\hline
\end{tabular}




\begin{tabular}{|c|c|c|}
\hline Proposed/Active Change & Description & Notes \\
\hline $\begin{array}{l}\text { Residential Demand } \\
\text { Charges }\end{array}$ & $\begin{array}{l}\text { Typical in U.S. commercial rates, } \\
\text { demand charges are a } \$ / \mathrm{kW} \text { fee } \\
\text { for a customer's highest } \\
\text { momentary usage (demand), } \\
\text { typically in a } 10 \text {-minute to } 30- \\
\text { minute interval. Such charges } \\
\text { often comprise the bulk of the } \\
\text { electric bill for commercial } \\
\text { customers whose per-kilowatt- } \\
\text { hour charges are low relative to } \\
\text { residential rates. }\end{array}$ & $\begin{array}{l}\text { There are currently no } \\
\text { statewide plans to mandate } \\
\text { demand charges for DG or } \\
\text { regular customers. However, } \\
\text { four U.S. utilities have } \\
\text { implemented them solely for } \\
\text { their DG customers. }\end{array}$ \\
\hline Value of Solar Tariffs & $\begin{array}{l}\text { All solar generation (not just the } \\
\text { net excess) is compensated at a } \\
\text { special rate that reflects its value } \\
\text { to the grid. Common points of } \\
\text { valuation include energy, } \\
\text { capacity, environmental qualities, } \\
\text { frequency regulation, voltage } \\
\text { control, avoided infrastructural } \\
\text { upgrades, and locational benefits } \\
\text { such as congestion relief and } \\
\text { distribution system upgrade } \\
\text { deferrals. }\end{array}$ & $\begin{array}{l}\text { Minnesota is currently the only } \\
\text { state that has a value of solar } \\
\text { tariff available as an alternative } \\
\text { to NEM though adoption is } \\
\text { currently optional; the City of } \\
\text { Austin, Texas has a municipal } \\
\text { value of solar tariff that is } \\
\text { applied to all systems in its } \\
\text { service territory. Numerous } \\
\text { other states have explored } \\
\text { this option as a replacement for } \\
\text { NEM. }\end{array}$ \\
\hline Customer Self-Supply & $\begin{array}{l}\text { A tariff structure where DGPV } \\
\text { hosts must consume all solar } \\
\text { generation when it is produced or } \\
\text { else store that generation in a } \\
\text { battery or other source (e.g., } \\
\text { water heater) for use when solar } \\
\text { power is unavailable-any } \\
\text { generation that is exported onto } \\
\text { the grid is uncompensated. } \\
\text { Moreover, the deployment of } \\
\text { advanced inverters on all self- } \\
\text { supply PV systems means excess } \\
\text { energy will get curtailed for grid } \\
\text { management purposes. Hosts are } \\
\text { still connected to the grid and } \\
\text { can, at any time access grid } \\
\text { power at the retail rate. Monthly } \\
\text { minimum bills for self-supply } \\
\text { customers are } \$ 25 \text { for residential } \\
\text { customers and } \$ 50 \\
\text { for commercial customers. }\end{array}$ & $\begin{array}{l}\text { Hawaii is the only state that } \\
\text { currently has a self-supply } \\
\text { program. While California } \\
\text { utilities have some special } \\
\text { tariffs for storage technologies, } \\
\text { these tariffs are not specifically } \\
\text { geared toward self- } \\
\text { consumption. The state's retail- } \\
\text { rate net metering program was } \\
\text { discontinued in } 2015 \text { and was } \\
\text { followed by two pilot programs: } \\
\text { a grid supply program (which } \\
\text { allowed for grid exports and } \\
\text { compensation below the retail } \\
\text { rate) and this self-supply } \\
\text { program. The grid supply } \\
\text { program has nearly reached its } \\
\text { program cap and availability is } \\
\text { limited. }\end{array}$ \\
\hline
\end{tabular}

Sources: Proudlove et al. 2016; Bird et al. 2013; Bird et al. 2015; Williard 2016;

EQ Research 2016; Taylor 2016 


\subsection{California}

California's history of robust incentives and mandates - coupled with comparatively high retail electricity rates and a progressive, adaptable regulatory construct - has put the state ahead of any other in terms of DGPV capacity. This growth, as well as the advent of storage, electric vehicle charging, and other emerging DG technologies, has precipitated several pieces of legislation; a flurry of regulatory rulemaking (both proposed and implemented); a raft of state and utility incentive programs; and an ongoing debate about the value and future role of DG. These developments are all unfolding against a backdrop of the state's recent renewable portfolio standard increase to $50 \%$ by 2030 ; its greenhouse gas reduction mandate of $40 \%$ below 1990 levels by 2030; its various baseload plant closures; challenges with grid reliability and plant ramping; and other market fundamentals that are directing utilities to procure incrementally more renewable energy, energy efficiency, and demand response (DR) resources.

A full discussion of California's policies, regulations, and incentives is beyond the scope of this report. As a summary, the following subsections identify select policies that are anticipated to have large impacts on DG deployment within the state and possibly serve as models for other jurisdictions.

\subsubsection{NEM 2.0 and Rate Changes}

In 2013, the California governor signed Assembly Bill (AB) 327, which directed the California Public Utilities Commission (CPUC) to implement a successor tariff to the then-current NEM laws. The motivation behind this directive was for the CPUC to arrive at regulations that would allow for the continued growth of rooftop solar but would be fair to all ratepayers (i.e., provide no cross-subsidization). The CPUC was to arrive at this tariff before the NEM cap of $5 \%$ of aggregate customer peak demand was achieved in the service territories of the state's three IOUs, or by January 1, 2017.

The CPUC issued its final decision on a successor tariff (i.e., NEM 2.0) in February 2016. The new tariff preserves significant features of the original NEM structurenamely, it does not reduce the compensation rate to below the full retail rate and it requires utilities to credit all excess generation. However, it does introduce some changes that could affect DGPV economics, including interconnection fees, non-bypassable charges, and a transition to TOU rates for DGPV customers. NEM 2.0 does not change the minimum bill beyond the $\$ 10$ standard that was established through $\mathrm{AB} 327$, and it prohibits the application of any further fixed or demand charges by a utility until the CPUC has analyzed the impacts to residential ratepayers (Trabish 2016).

Another change in DGPV economics in California could come with the scheduled "flattening" of the user tiers. ${ }^{5}$ The previous tier structure in California had four blocks of usage, segmented by usage levels, with Tier 3 and Tier 4 users paying rates in excess of

\footnotetext{
${ }^{5}$ In tiered rate structures, users pay higher rates as they use increasingly more energy. This is also known as a block rate structure because volumetric charges are based on blocks of energy usage. In California, the blocks are defined by the percentage of the state baseline that customers use (i.e., users of $100 \%$ of the baseline are in Tier 1, users at $120 \%$ of the baseline are in Tier 2, and users over $200 \%$ are in Tier 3 ).
} 
$\$ 0.25 / \mathrm{kWh}$ and as high as $\$ 0.31 / \mathrm{kWh}$ for electricity use that surpassed a certain percentage of the state baseline usage. Tier 3 and Tier 4 users were the utility customers for whom solar provided the greatest economic value. The scheduled new tier structure will collapse the four tiers into two (currently, there are three) and will annually reduce the premium that higher tier users pay over the lower tier.

In 2016, the highest tier paid $76 \%$ more than the lowest tier for electricity use over $200 \%$ of the state baseline. In 2019, this premium will only be $25 \%$ (Roth 2015). This process will gradually shift high-energy users into lower-charge blocks, potentially reducing their monthly electric bills and the value that a solar energy offset could provide. In 2017, California will designate a "super-user" category that will include ratepayers who consume $400 \%$ over the California baseline. The premium on electricity charges for this tier will rise each year to $119 \%$ by 2019 . This category of user could still realize beneficial economics from solar installations with fully loaded NEM rates (Roth 2015).

\subsubsection{Storage}

Some analysts predict that the near-term continuance of NEM - even in its modified state - will slow the uptake of storage (Dehamna, Eller, and Tokash 2016). As long as excess PV generation fed onto the grid is compensated at fully loaded retail rates, the economics of battery storage will be uncompetitive at current and projected near-term cost levels. To address the challenges of cost and economics, California issued a statewide mandate-AB 2514 - in 2013 that directs the state's three IOUs to procure storage resources totaling 1.3 gigawatts (GW). In August 2016, California modified an existing incentive program - the Self-Generation Incentive Program (SGIP) - to focus the bulk of its funds on storage cost reduction.

SGIP is a rebate program begun in 2001 to support various distributed generation technologies that the CPUC considered valuable to the grid. The program was modified in the summer of 2016 to devote $75 \%$ of its funds to storage technologies, with $15 \%$ of that portion dedicated to residential projects (CPUC 2016a). These recent modifications, in concert with $\mathrm{AB} 2514$ and concerns over the continued viability of NEM are anticipated to grow storage demand and drive technology cost reductions (Dehamna, Eller, and Tokash 2016).

SGIP offers upfront rebates to eligible technologies based on forecasted production (in watt-hours) over the lifetime of the eligible technology. Prior to June 2016, rebates were paid based on capacity (in watts), but the policy was changed to reward for highperforming batteries with additional incentive value (Roselund 2016). Additionally, the program was modified to a block grant structure. SGIP had an annual budget ( $\$ 83$ million) up until 2016, but the new version of the program will receive one lump sum and funds will be steadily spent down until 2020. Grant values will decline at certain levels of depletion of the original fund. Table 2 shows the step-down schedule. 
Table 2. SGIP Incentive Step-Down Schedule

\begin{tabular}{|llllll|} 
& Step 1 & Step 2 & Step 3 & Step 4 & Step 5 \\
\hline $\begin{array}{l}\text { Large Scale Energy Storage } \\
(>10 \text { kW) without ITC }\end{array}$ & $\$ 0.50 / \mathrm{Wh}$ & $\$ 0.45 / \mathrm{Wh}$ & $\$ 0.40 / \mathrm{Wh}$ & $\$ 0.35 / \mathrm{Wh}$ & $\$ 0.30 / \mathrm{Wh}$ \\
\hline $\begin{array}{l}\text { Large Scale Energy Storage } \\
(>10 \mathrm{~kW}) \text { with ITC }\end{array}$ & $\$ 0.36 / \mathrm{Wh}$ & $\$ 0.31 / \mathrm{Wh}$ & $\$ 0.26 / \mathrm{Wh}$ & $\$ 0.21 / \mathrm{Wh}$ & $\$ 0.16 / \mathrm{Wh}$ \\
\hline $\begin{array}{l}\text { Residential Energy Storage } \\
(\leq 10 \mathrm{~kW})\end{array}$ & $\$ 0.50 / \mathrm{Wh}$ & $\$ 0.45 / \mathrm{Wh}$ & $\$ 0.40 / \mathrm{Wh}$ & $\$ 0.35 / \mathrm{Wh}$ & $\$ 0.30 / \mathrm{W}$ \\
\hline
\end{tabular}

Source: CPUC 2016a

$\mathrm{Wh}=$ watt-hour

Today, storage relies on DGPV deployment because the economics of batteries are greatly improved when paired with a DGPV system (the reverse can be true as well) (Dehamna, Eller, and Tokash 2016). Some California utilities, recognizing the value of $\mathrm{PV}$ with storage systems as grid assets, have begun considering special rates to customers who install them. For example, San Diego Gas and Electric's proposed "Bring Your Own Battery Tariff" would place storage customers on a dynamic rate schedule that would allow the utility to charge and discharge the battery at times when it would optimally assist the grid (St. John 2015a). California utilities are also experimenting with rates and services to better serve the specific characteristics of DG technologies. Pacific Gas and Electric offers a special rate plan to owners of electric vehicle charging units. The rate plan breaks out electric vehicle charging costs from those of the home (PG\&E 2016).

\subsubsection{Demand Response and Aggregation}

Though it is neither a generation source nor a "technology" by strict definition, DR warrants mention. California utilities and its independent system operator are increasingly using DR as a distributed resource to manage the grid. CPUC Decision 1211-025 (later amended by Decision 13-12-029) directs California's three IOUs to implement direct participation DR programs, and the rules governing such programs are codified in Electric Rule 24 and Rule 32. Direct participation DR allows retail utility customers - residential, commercial, and industrial — to bid reductions in their energy demand as a resource into the wholesale markets and receive remuneration. Retail customers can either bid directly (if they meet certain criteria) or contract with a "DR provider" - a third party that aggregates DR resources and bids them into the wholesale market as a portfolio (CPUC 2016b).

California has also implemented a pilot tender process, called the Demand Response Auction Mechanism (DRAM), to facilitate IOUs' procurement of DR resources to meet their resource adequacy requirements. California has partly modeled its approach after the PJM Interconnection - the largest independent system operator in the United Statesand its auction mechanism to allow for price formation in an open and transparent process of discovery (as opposed to using bilateral contracts). The direct participation rules and DRAM program allow a nascent class of DR resources - such as smart thermostats, electric vehicle charging, and batteries - to participate in a market that has been traditionally reserved for commercial and industrial participants (St. John 2015b). 
Third-party aggregation of resources may not only benefit DR but could also allow DG resources to participate in wholesale markets and provide grid services such as peak load shaving and load shifting. The California Independent System Operator (CAISO) recently received approval from the Federal Energy Regulatory Commission to modify its Open Access Transmission Tariff to facilitate the participation of aggregated DG resources in wholesale energy and ancillary services markets (FERC 2016). One aggregation pilot program is currently underway in Southern California Edison's service territory. Third-party solar provider SolarCity, in partnership with the SunSpec Alliance, will install up to $500 \mathrm{~kW}$ of solar and storage systems on a specific distribution circuit and will aggregate them to provide ancillary services (voltage control and frequency regulation) to the CAISO ancillary services market. The project will also showcase how advanced inverter functionality can provide the critical link between PV systems and external receivers, including batteries and grid operators, to enable this kind of aggregation model (St. John 2015c).

The procurement of aggregated resources such as those to be demonstrated through this pilot program could become more common in California as the state's three IOUs begin incorporating DG resources into their planning processes. As per AB 327, the IOUs are required to submit distribution resources plans to the CPUC that document the state of play and the plans these utilities have regarding the integration of DG into their operations and long-term system buildouts (CPUC 2016c). Whereas utilities in the United States have hitherto taken a largely passive role in DG, essentially deferring siting and operations decisions to its customer base and third-party installers, these distribution resource plans represent a mandate to take a more active role. Accordingly, California's three IOUs (and several other utilities in the state) must now develop the tools, software, communications, incentive programs, and other critical infrastructure to manage a portfolio of decentralized systems. The New York utility regulator has made a similar demand on the six IOUs in its service territory, as will be discussed in Section 2.4.1

\subsection{New York}

In 2014, under the leadership of Governor Andrew Cuomo, the state of New York embarked on its Reforming the Energy Vision or REV initiative, a structural overhaul of its energy system. The stated primary objective of the initiative is to build a clean, resilient, and more affordable system for state residents. REV envisions a transformation in the way that electricity is generated and delivered to meet the needs of an increasingly distributed system. REV encompasses numerous sub-initiatives, ranging from utility business model reform, creation of a distributed system platform to integrate more DG resources onto the grid, broadening access to renewable energy, and addressing the energy burden of the state's low-income residents. ${ }^{6}$ However, broadly defined, the reform is comprised of three "core pillars," each housed within its own state agency:

- Regulatory Reform: the New York Public Service Commission (NYPSC - the state utility regulator) has begun the process of reorganizing the energy system and implementing the corresponding regulatory paradigm to create a distributed system platform (DSP). The DSP is envisioned as an open market in which third

\footnotetext{
${ }^{6}$ For a general listing of these initiatives, see the Reforming the Energy Vision whitepaper (REV 2016).
} 
party owners of DG technologies can provide energy and other grid services from their assets. To accomplish this, the NYPSC has instituted numerous initiatives and rulemakings to restructure utility business models and define performance metrics and tariff designs. The ultimate goal is to realign utility incentives, such that utility revenue would be tied to effective support of a decentralized DSP. The REV proceeding docket has been open since 2014.

- Market Creation/Stimulation: The NYPSC has also approved a 10-year, $\$ 5$ billion fund to be placed under the management of the New York State Energy Research and Development Authority for the purpose of (1) reducing market barriers to the adoption of PV and other renewable and distributed technologies, and (2) leveraging private investment in the various REV initiatives. This Clean Energy Fund makes its investments via four entities: the New York Green Bank (which provides financial products for enterprises that advance the REV mission); the NY Sun program (a solar expansion initiative); Market Development; and Innovation and Research.

- New York Power Authority Investments in Innovation: The New York Power Authority is a self-sustaining state public power organization that operates generation facilities and transmission lines, and sells electricity to various classes of public and private users (but not directly to residential consumers). Under $\mathrm{REV}$, the New York Power Authority is making investments in emerging technologies and demonstration projects, as well as grid upgrades that are anticipated to advance the environmental, social, economic, and resiliency goals of the initiative (REV 2016).

$\mathrm{REV}$ is a broad reform that seeks to address a host of challenges and barriers through radical structural reform. However, the following two subsections (2.4.1 and 2.4.2) focus solely on the first pillar of the initiative: the proposed regulatory measures. The NYPSC's docket on REV is split into two regulatory tracks: one on the development of a new DG marketplace (called the distributed system platform or DSP) and one on the utility ratemaking. As of this writing, the docket is still open and both tracks are continually evolving - in other words, no final rulemaking has yet been issued to implement any of the changes discussed next.

\subsubsection{The Distributed System Platform}

The NYPSC envisions the DSP as a digital marketplace that facilitates two-way flows of information and energy between DG owners and the utilities or platform providers and where multi-sided transactions between all parties on the grid would be possible (NYPSC 2016a). The DSP is intended to be a customer-facing marketplace where DG owners can be compensated for their electricity and grid services based on a location-specific price. With price formation pegged to locational benefits, the DSP could incentivize optimal distribution of DG resources on the grid where they are most needed.

A 2015 whitepaper by the Market Design and Platform Technology (MDPT) Working Group convened by the NYPSC (MDPT 2016) identified five key functions and capabilities that the DSP will require to operate effectively. These are: 
- Enhanced distribution planning to (1) allow better integration of DG resources into the distribution system and (2) better coordinate distribution system planning and transmission planning

- Expanded distribution grid operations to better optimize load and energy supply, manage bidirectional power flows, improve cyber-security, and provide other services required to run a next-generation grid architecture

- Distribution market operations to optimize DG value and deployment, including standardizing the products to be transacted, the formation of market rules, facilitating and processing transactions, and tracking participant performance

- Data requirements that will provide market participants with the requisite information to successfully bid into the market

- Platform technologies, including geospatial models of connectivity and system characteristics, sensing and control technologies for system reliability, optimization tools that take DR into account with the generation output of existing and new DG generators, and communications technologies; the execution of the previous four capabilities will depend on the implementation of these several technologies.

The NYPSC has also required that New York distribution utilities file distributed system implementation plans, which provide a baseline assessment of the each utility's system and capabilities, as well as a five-year roadmap for the transition to a DSP. Initial plans were submitted on June 30, 2016, and the six state IOUs jointly submitted a supplemental plan on November 1, 2016. These implementation plans parallel the distribution resources plans that the California PUC requires of several of its utilities to identify both optimal locations for DG on the system and strategies for integration (Joint Utilities of New York 2016).

\subsubsection{Transition From Net Metering}

A critical component of REV will be the development and accurate valuation for DG services that move beyond what some have termed the "blunt instrument" of NEM (Kann 2016). As part of the New York Commission's Value of Distributed Energy Resources proceeding over the past year, stakeholders (including New York utilities, solar companies, environmental groups, and consumer groups) have worked cooperatively to develop a successor tariff as the initial step towards a more precise DG valuation and compensation methodology (NYSPC 2016a). If adopted by the Commission, this successor tariff would value and compensate DGPV and other eligible DG generators based on a more granular identification and quantification of various value components associated with the bulk and distribution systems as well as societal factors.

The New York Department of Public Service has produced a report outlining a "Phase One" mechanism that includes methodologies for deriving value for energy, capacity, distribution and environmental values associated with DG. Energy and capacity value would be derived from the wholesale New York Independent System Operator markets, with alternative options presented for intermittent and dispatchable DG technologies. Environmental value would be based on the New York State Energy Research and 
Development Authority's (NYSERDA) latest published Tier 1 REC sale price with the EPA's social cost of carbon serving as a floor (NYPSC 2016).

Valuation of the distribution component (or "D") is evolving. The NYPSC Staff's initial recommendations in the report will lay the groundwork, and in some cases offer specific methodologies, for uncovering the value of $\mathrm{D}$ in the Phase One mechanism and for continuing the investigation. In at least one Order, the NYPSC has cited that D should account for values associated with the distribution system including: load reduction, frequency regulation, reactive power, line loss avoidance, resilience and locational values. As explained in the report, the NYPSC staff anticipates that collaborative discussions with stakeholders to close in on a $\mathrm{D}$ valuation methodology will continue into subsequent phases of the proceeding. Other stakeholders are commenting on the report as of this writing.

\subsubsection{Utility Business Models and Ratemaking}

In addition to their critical function of maintaining system reliability, utilities will be responsible for providing and operating the DSP. This new paradigm upends the traditional model where utility earnings are driven by returns on capital investments (i.e., the cost-of-service model). Instead of an environment where the utility is incentivized through earning a regulated return, the next generation of New York utilities will be incentivized through market-based earnings and performance incentives. In other words, utilities will be compensated for efficiently facilitating value-enhancing DG access to and integration with the grid (NYPSC 2015). The revenue derived from maximizing the DG potential and functionality/reliability of the grid would offset, in part, the utilities' opportunity cost of not investing in capital expenditures.

This transition renders the utility a platform provider, or, as one utility executive phrased it, the "air traffic controller" of the distribution system (Savenije 2015). Concomitant to the change in business model will be a change in rate structures. The NYPSC has recommended that general rates should adopt a more time-based design, where the hours of customer peak demand would receive higher price weighting than other times of the day. This would incentivize customers to invest in DG technologies and/or home energy management solutions to flatten demand spikes and save money. The NYPSC has recommended that customers who employ these measures be eligible to opt into a "smart home rate," which would unbundle granular price signals for DG value streams such as energy, ancillary services, grid support, and others. By responding to each of these price signals - likely through optimization software, inverter controls, and other mechanismscustomers would effectively be providing behind-the-meter management of their DG resources as well as greater resilience to the grid. 


\section{Germany}

As of the beginning of 2016, Germany's installed PV capacity topped $40 \mathrm{GW}, 98 \%$ of which could be considered "distributed" (i.e., it is interconnected at the low-voltage distribution level and serves load close to the system) and 50\% of which is under ownership of private citizens (Wirth 2016; Weimar et al. 2016). PV comprises nearly a quarter of the installed generation capacity in Germany, and, on days of high production, PV can meet over a third of Germany's momentary peak demand (Heinrich Böll 2016; Wirth 2016).

The mass deployment of PV (and other renewables) in Germany owes largely to the country's FiT policy. Until its restructuring in 2012 and 2014 amendments to the Renewable Energy Sources Act (Erneuerbare Energien Gesetz or EEG), Germany's FiT policy was one of the most robust renewable energy support policies in the world. In 2012, FiT rates were significantly reduced for all classes of PV systems and a monthly schedule of remuneration reductions was instituted. This resulted in successive declines in annual PV installations: 56\% in 2013 and another 42\% in 2014 (Anand 2016).

Reforms to the EEG have been partly motivated by various complications arising from steep levels of renewable penetration. As variable generation takes on a larger proportion of total generation (12.6\% of final consumption in 2015), grid management challenges and negative prices at times of high renewable energy supply in Germany's energy market have become major challenges (BNEF 2016a). Moreover, the country has doubled down on its commitment to shutter its entire nuclear fleet by $2022,{ }^{7}$ which leaves gaps in its baseload portfolio (Heinrich Böll 2016).

Another driver of the successive EEG reforms over the last five years has been the increase in retail electricity prices corresponding to the rapid expansion of the renewable capacity across the country. To fund the FiT, Germany's transmission system operators collect a surcharge from electricity consumers to remit to renewable energy generators.

These surcharges were partly the cause of an electricity price growth rate of $4.59 \%$ per year from 2006 to 2014 (compound annual growth). From 2012 to 2013 alone, prices spiked 12.5\% (Weimar et al. 2016). Today, Germany has some of the highest residential electricity prices in Europe at about $€ 0.31 / \mathrm{kWh}$ as of this writing (Hoff 2016; Weiss 2014). The increasing grid challenges mentioned above are also a reason for the price increases.

It is important to note that the rising price of electricity in Germany is not solely the result of the EEG surcharge (the premium charged on each kilowatt-hour to fund FiT payments to generators). In fact, the surcharge, which will increase to $€ 0.0688$ in 2017 , represents over a fifth of the total retail electricity price at today's levels; PV-specific support is roughly a twentieth — see Figure 1 for 2014 data (Weiss 2014; Wirth 2016; Clean Energy Wire 2016). Heavy electricity users in trade-sensitive areas are partially exempt from the EEG surcharge, which has shifted the burden of renewables support to German households ( $\approx 30 \%$ of total German power consumption) (Wirth 2016;

\footnotetext{
${ }^{7}$ A total of $9.7 \mathrm{GW}$ have been taken offline since 2011.
} 
Weiss 2014). The exemptions for commercial and industrial users represents about $20 \%$ of Germany's entire power consumption and cost nearly $€ 5.1$ billion in 2014

(Wirth 2016).

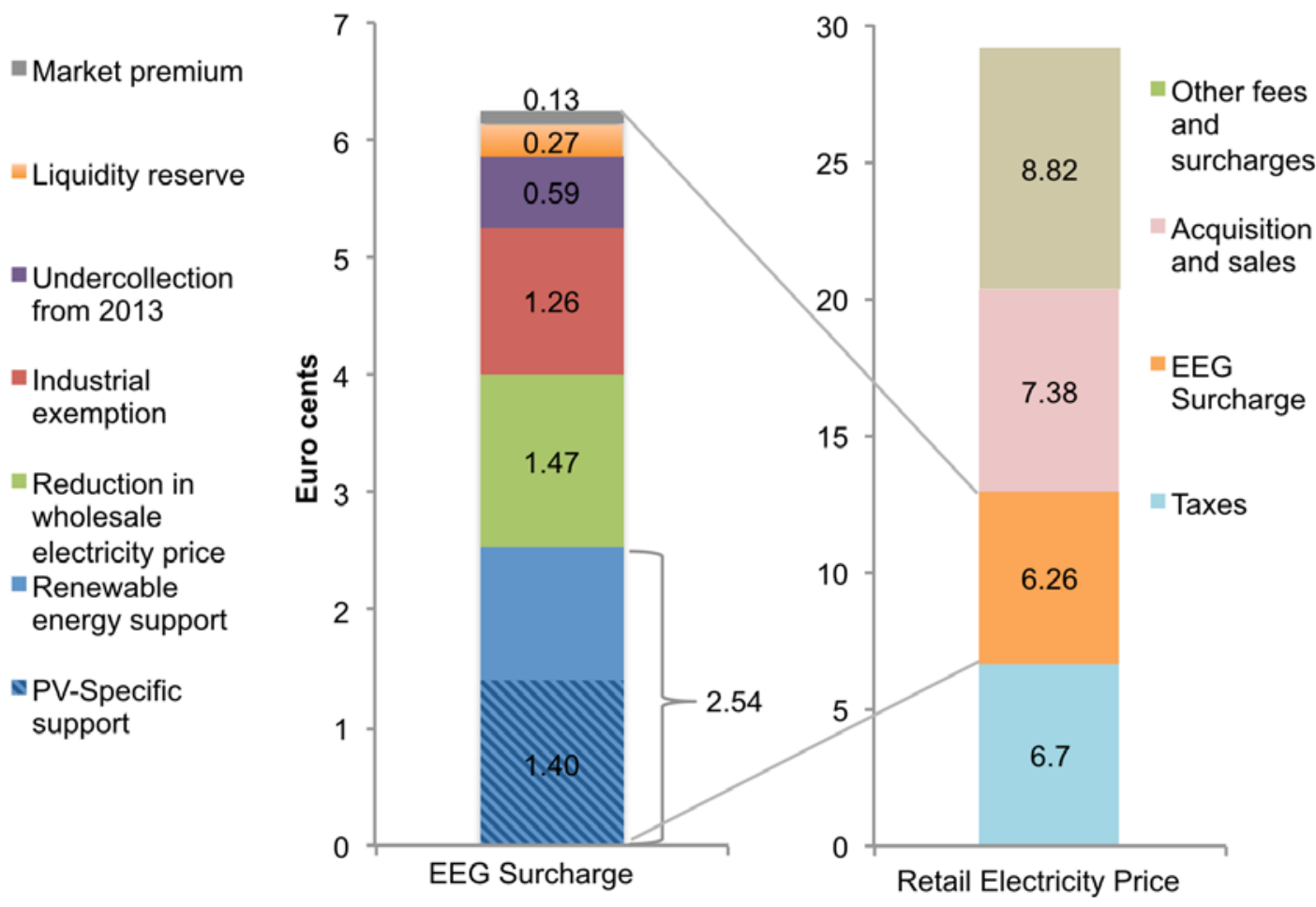

Figure 1. Makeup of Germany's 2014 EEG surcharge (left) and 2014 retail electricity price (right)

Source: Data from Wirth 2016

Remunerations to PV generators under the FiT and feed-in premium scheme (see Section 3.1) will persist until the country reaches $52 \mathrm{GW}$ of capacity, at which time both policies are scheduled to sunset (only for PV) (Wirth 2016). Annual PV installations have declined 80\% since the implementation of the 2012 reforms (see Figure 2). 


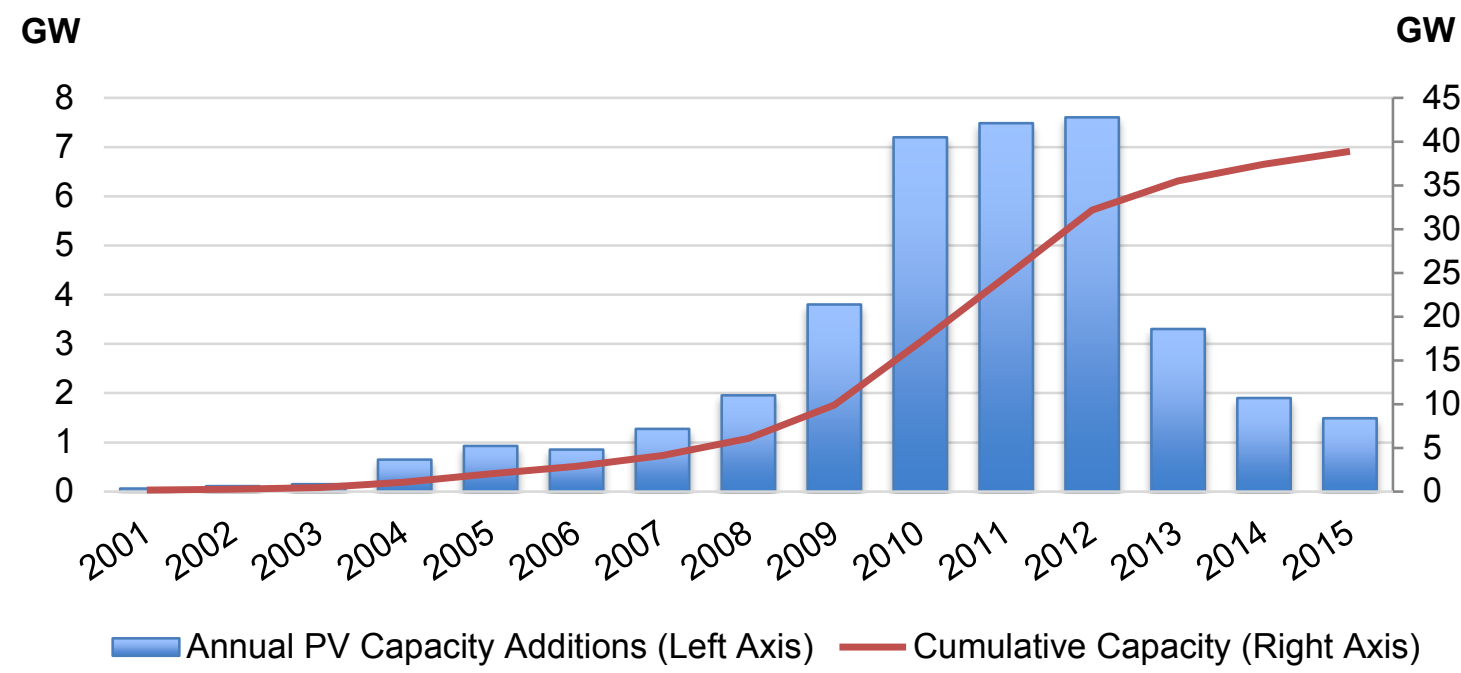

Figure 2. Annual and cumulative installed PV capacity in Germany, 2001-2015

Source: Data from BNEF 2016a

Despite the challenges that a ballooning renewable energy portfolio has brought (and the resultant retrenchment of support policies), Germany's policy goals remain aggressive. The renewables portion of gross electricity consumption totals $40 \%-45 \%$ by $2025,55 \%-$ $60 \%$ by 2035 , and $80 \%$ by 2050 ,but the country is presently on track to meet them (EU Tracking Roadmap 2015).

Sections 3.1 through 3.5 discuss the provisions of the 2012 and 2014 reforms that have had the most significant impact on DGPV deployment. Taken collectively, these provisions illustrate Germany's attempts to transition support of DGPV (and renewables in general) away from direct support and toward a more market-driven regime. Section 3.6 briefly reviews incentives currently on offer to spur the deployment of other DG resources, namely storage and CHP.

\subsection{Feed-in Premiums}

The 2012 revision to the EEG introduced a "feed-in premium" (FiP) scheme as an optional alternative to the FiT. Under this scheme, renewable energy generators above a certain size threshold could choose to forgo guaranteed FiT payments and sell their electricity directly into the energy market at a premium to the spot price (i.e., the market clearing price on the European Power Exchange). This premium was sized to bring total compensation per kilowatt-hour in line with what the system owner would have received under the FiT, affording generators a comparable level of compensation. The "differential cost" is the difference between the spot price and the tariff amount.

For all PV systems between $500 \mathrm{~kW}$ and $10 \mathrm{MW}$, the 2014 EEG revision replaced the FiT with the FiP. The lower bound of that range was adjusted downward to $100 \mathrm{~kW}$ on January 1, 2016. Under the current version of the law, PV (and other renewable) generators still receive feed-in priority to the grid, but they are otherwise required to sell their generation, normally to direct marketing firms who purchase the energy at the 
applicable premium and then sell it on the European Power Exchange. Table 3 lists premium and FiT rates as of September 2016. It is worth noting that the difference between the two for each category of project size is les than a whole euro cent.

Table 3. German FiP and FiT Rates, July-September 2016

\begin{tabular}{|l|l|l|}
\hline Project Size & FiP Rate $(\boldsymbol{\epsilon} / \mathbf{k W h})$ & FiT Rate $(\boldsymbol{\epsilon} / \mathrm{kWh})$ \\
\hline$<10 \mathrm{~kW}$ & 0.127 & 0.1231 \\
\hline $10-40 \mathrm{~kW}$ & 0.1236 & 0.1197 \\
\hline $40-500 \mathrm{~kW}$ & 0.1109 & 0.1071 (up to $100 \mathrm{~kW})$ \\
\hline Free-standing projects & 0.0891 & 0.0853 \\
\hline
\end{tabular}

Sources: BNEF 2016a; Enkhardt 2015

Systems below $100 \mathrm{~kW}$ are still eligible to receive the full FiT for each kilowatt-hour of energy produced, though for systems between $10 \mathrm{~kW}$ and $100 \mathrm{~kW}$, only $90 \%$ of total production will be covered (BNEF 2016a). Systems larger than $10 \mathrm{MW}$ have been unsupported by the FiT or FiP schemes since 2012, and they must compete on a level basis with other generators in the energy markets; this has effectively stopped development in this market segment. All PV systems that were installed before August 1, 2014 (the effective date for the 2014 EEG) will continue to receive the full tariff payment for 20 years after their operation date (Wirth 2016; BNEF 2016a).

\subsection{Auctions}

In addition to the direct marketing requirement, the 2014 EEG initiated a pilot tender process for an aggregate capacity of $1.2 \mathrm{GW}$ of ground-mounted PV systems up to $10 \mathrm{MW}$ in size to be auctioned off to the most competitive bids between the years 2015 and 2017. Auctions have been scheduled to occur three times per year, and five have been held as of this writing (Table 4).

Table 4. Germany PV Auctions for Large-Scale Ground-Mount, 2015-2016

\begin{tabular}{|l|c|c|c|c|}
\hline Date of Auction & $\begin{array}{l}\text { Capacity } \\
\text { Auctioned } \\
\text { (MW) }\end{array}$ & $\begin{array}{l}\text { Average } \\
\text { Winning Bid } \\
(\boldsymbol{\epsilon} / \mathbf{k W h})\end{array}$ & $\begin{array}{l}\text { \% Decrease from } \\
\text { Previous Winning } \\
\text { Bid }\end{array}$ & $\begin{array}{l}\text { \% Decrease from } \\
\text { Original Winning } \\
\text { Bid }\end{array}$ \\
\hline April 2015 & 150 & 0.092 & & 7.7 \\
\hline August 2015 & 150 & 0.085 & 7.7 & 13 \\
\hline December 2015 & 200 & 0.08 & 5.8 & 19.5 \\
\hline April 2016 & 125 & 0.074 & 7.4 & 21.4 \\
\hline August 2016 & 130 & 0.072 & 2.4 & 25 \\
\hline December 2016 & 163 & 0.069 & 4.6 & \\
\hline
\end{tabular}

Sources: BNEF 2016a; PV Enkhardt 2016; Tsanova 2016

Bid prices are capped at the FiT rate for PV systems from $40 \mathrm{~kW}$ to $100 \mathrm{~kW}$. Winning projects are "paid as bid," meaning the bid price is what generators receive per kilowatt- 
hour of electricity generated for 20 years. The second and third tenders (August and December of 2015) experimented with a pay-as-clear system, where all selected projects are paid the per-kilowatt-hour price of the highest winning bidder.

All bidders must pay a deposit of $€ 4 / \mathrm{kW}$, and auction winners must pay a secondary deposit of $€ 50 / \mathrm{kW}$ within ten business days of the announcement of winning bids. Thus far, these auctions have been well oversubscribed, with the most recent (December 2016) drawing 76 bids for 423 MW tendered. The next auction is scheduled for February 2017.

\subsection{Tariff Degressions}

The 2012, EEG introduced monthly FiT rate degressions (i.e., reductions) based on installation volume from the previous year. The German government has set a series of capacity ranges, or "corridors," that dictate certain degressions to the FiT and the FiP. Under current law, the minimum tariff reduction is $0.25 \%$ per month for the capacity corridor of 1.5-2.4 GW in the previous year. The government's target corridor is 2.4-2.6 GW (which would entail a $1 \%$ per month cut the following year). Degressions are capped at $2.8 \%$ per month for deployment in excess of $7.5 \mathrm{GW}$ (which was the high water mark in 2012). Degressions only apply to systems below $100 \mathrm{~kW}$ (i.e., those systems that are not required to participate in the auction process). See Table 5.

\section{Table 5. German Tariff Degressions by Capacity Corridor}

\begin{tabular}{l}
\hline \begin{tabular}{|l|c|}
\hline $\begin{array}{l}\text { Capacity } \\
\text { Corridor (GW) }\end{array}$ & $\begin{array}{l}\text { Monthly } \\
\text { Degression (\%) }\end{array}$ \\
\hline$\geq 7.5$ & 2.8 \\
\hline $6.5-7.5$ & 2.5 \\
\hline $5.5-6.5$ & 2.2 \\
\hline $4.5-5.5$ & 1.8 \\
\hline $3.5-4.5$ & 1.4 \\
\hline $2.6-3.5$ & 1.0 \\
\hline $2.4-2.6$ & 0.5 \\
\hline $1.5-2.4$ & 0.25 \\
\hline $1.0-1.5$ & 0 \\
\hline 51 & $-1.5^{\text {a }}$ \\
\hline
\end{tabular} \\
anly for the first month of the quarter; the tariff will not be \\
reduced in the remaining two months of the quarter. \\
Source: BNEF 2016a
\end{tabular}

The fourth quarter of 2015 marked the first time since the 2012 EEG that tariff levels did not degress. The total installed PV capacity for that year was anticipated to fall below the 1.5-GW threshold at which a degression would trigger. Since the third quarter of 2015, premium and tariff rates have remained unchanged (Enkhardt 2015). 


\subsection{Self-Consumption}

Self-consumption is the local use of PV electricity for the purpose of reducing load at or near the site of the system. Necessarily, self-consumption precludes feeding PVgenerated electricity back onto the grid where it would receive tariff rates. This means that in order for self-consumption to be economic for generation owners, the retail electricity rate must be high enough (and the tariff rate low enough) that the offset to load is more valuable than what that same electricity would fetch in remunerations. At a high level, this analysis can be easily performed by looking at retail rates per kilowatt-hour versus tariff rates per kilowatt-hour - the higher of the two will dictate whether selfconsumption or FiT payments produce more favorable economics.

Self-consumption has grown among PV hosts in Germany as retail electricity prices rise and as tariff rates and PV system costs decline. With a lower cost to produce electricity from a PV system, the delta between the retail rate and the levelized cost of energy widens. This affords self-consumers greater value for their energy (assuming peak system production and peak load are coincident). However, the economics of self-consumption for systems over $10 \mathrm{~kW}$ changed on August 1, 2014, when reforms to the EEG dictated that self-consumed electricity would be partially subject to the EEG surcharge. The applicable percentage of the surcharge began at 30\% and was stepped up on January 2016 to $35 \%$. At the beginning of 2017, the applicable percentage of the surcharge will be 40\%. All systems over $10 \mathrm{~kW}$ that were commissioned between August 1, 2014 and December 31, 2016 - regardless of what percentage of the surcharge they were subject to at the time of operation-will be required to pay the full $40 \%$ by 2017 . Systems commissioned before August 1, 2014, will continue to be exempt from paying the surcharge, as will residential systems less than $10 \mathrm{~kW}$ (PV Grid 2014). Generally, German households with PV consume $20 \%-40 \%$ of their system's production (Wirth 2016).

\subsection{Other Distributed Generation Support Mechanisms}

\subsubsection{Storage}

Germany's current storage incentive scheme, which was renewed in March 2016 after an initial implementation in 2013, consists of a low-interest loan of up to $€ 2 / \mathrm{W}$ for the PV system and a direct payment for up to $22 \%$ of the eligible costs of the system (not to exceed $€ 0.50 / \mathrm{W}$ of the PV capacity). The portion of eligible costs to which the grant can be applied will decrease by three percentage points every six months until it reaches $10 \%$ in the second half of 2018 , at which time the program will expire.

This incentive scheme is largely responsible for the residential storage sector's surge to $\$ 149$ million in market size in 2015 (BNEF 2016a). Storage systems can assist German ratepayers in self-consuming the electricity generated by their PV systems, which, even with the partial EEG surcharge, effectively reduces their retail electricity rate.

Notwithstanding its continued support for storage, the German government anticipates that this technology will not be crucial to grid support in the near future. The expectation is that reducing baseload generation and encouraging flexibility in the power system will 
obviate the need for storage capacity to smooth out the variability of renewables for another decade or longer (Heinrich Böll 2016).

\subsubsection{Combined Heat and Power}

Germany has targeted 110 terawatt-hours (TWh)/year of generation from CHP facilities by 2020 and $120 \mathrm{TWh} /$ year by 2025. In support of this goal, the government rolled out an updated version of its CHP Act on January 1, 2016, which increased maximum annual funding amounts from $€ 750$ million to $€ 1.5$ billion. The update also extends support to CHP systems that advance the development of district heating and heat and cold storage, while at the same time, it disqualifies CHP systems that are fueled by coal (Gailfuß 2016).

The new law is considerably more complex than previous iterations, with several categorizations of surcharges depending on system size and electricity use (see Table 6). As with PV, generators over a certain size (100 kW for CHP units) are required to directly market any energy that is not self-consumed. Units larger than $50 \mathrm{~kW}$ are eligible for funding support up to 30,000 full load hours, while units $50 \mathrm{~kW}$ or smaller are eligible up to 60,000 load hours. Systems with special designations (i.e., deemed compliant with the Greenhouse Gas Emissions Trading Act and/or designated as a gas-fired CHP generator that replaces a coal-fired CHP generator) receive additional support, though these amount to less than a full euro cent/kWh (Gailfuß 2016).

Table 6. CHP Generator Compensation by System Use and Size ${ }^{a}$

System Size (kW)

\begin{tabular}{|l|l|l|l|l|l|}
\hline System Use & $<\mathbf{5 0}$ & $\mathbf{5 0 - 1 0 0}$ & $\mathbf{1 0 0 - 2 5 0}$ & $\mathbf{2 5 0 - 2 0 0 0}$ & $\mathbf{2 0 0 0}$ \\
\hline $\begin{array}{l}\text { CHP electricity within the general } \\
\text { supply grid }\end{array}$ & 8 & 6 & 5 & 4.4 & 3.1 \\
\hline $\begin{array}{l}\text { CHP electricity outside of the } \\
\text { general supply grid }\end{array}$ & 4 & 3 & 2 & 1.5 & 1 \\
\hline $\begin{array}{l}\text { CHP electricity from independent } \\
\text { power producers outside of the } \\
\text { general supply grid }\end{array}$ & 4 & 3 & 2 & 2.4 & 1.8 \\
\hline $\begin{array}{l}\text { Self-usage of energy-intensive } \\
\text { undertaking }\end{array}$ & 5.41 & 4 & & \\
\hline $\begin{array}{l}\text { Systems within the Greenhouse } \\
\text { Gas Emissions Trading Act }\end{array}$ & +0.3 & +0.6 & & \\
\hline $\begin{array}{l}\text { Gas-fired CHP plants that } \\
\text { replace coal-fired CHP }\end{array}$ &
\end{tabular}

a All values are in euro cents per kWh.

Source: Gailfuß 2016 


\section{The United Kingdom}

\subsection{Distributed Generation: Development Status and Future Projections}

DG in the U.K. consists of many types and sizes of electricity generating plants that are connected to a distribution network, including PV, CHP, wind, and hydro plants. The growth of each respective technology has been uneven, with PV providing the majority of capacity additions since 2013 (see Figure 3), but overall, the sector has seen a nearly $500 \%$ increase in deployments since 2010.

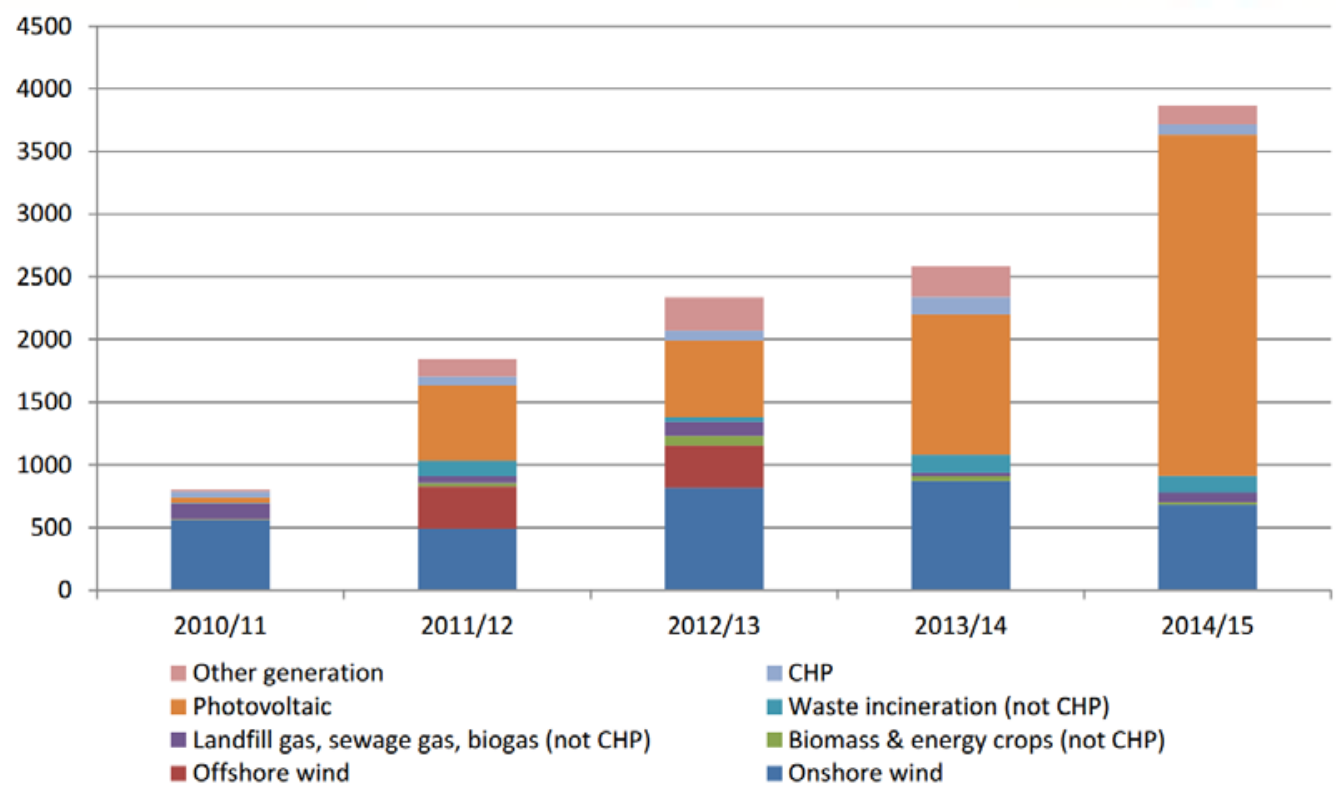

Figure 3. Annual DG installations in the U.K. by technology (MW)

Source: Data from Burgess 2015

A 2015 survey of senior leaders in the U.K.'s energy industry revealed that the prevailing opinion among this demographic is that DG will continue to grow rapidly in the near future. Many of these leaders believed that technologies such as PV, battery storage, small-scale gas, and micro-CHP could play a major role in the energy system by 2030 (Energy UK 2016). However, some analysts project that with the phase-out of the current FiT in 2019, DGPV deployment will decline until 2021 and storage would not take off until 2033 (BNEF 2016b). Section 4.2 addresses other policy changes that could precipitate this slowdown.

Despite the U.K.'s near-term outlook for installations, its goals and targets prescribe significant DG capacity build-out over the next 20 years. According to the U.K. utility National Grid's 2015 Future Energy Scenarios (National Grid 2015a), if the country achieves all of its carbon targets on time (as projected in the "Gone Green" scenario in Figure 4), it will have deployed 27.7 GW of DG by 2036. 


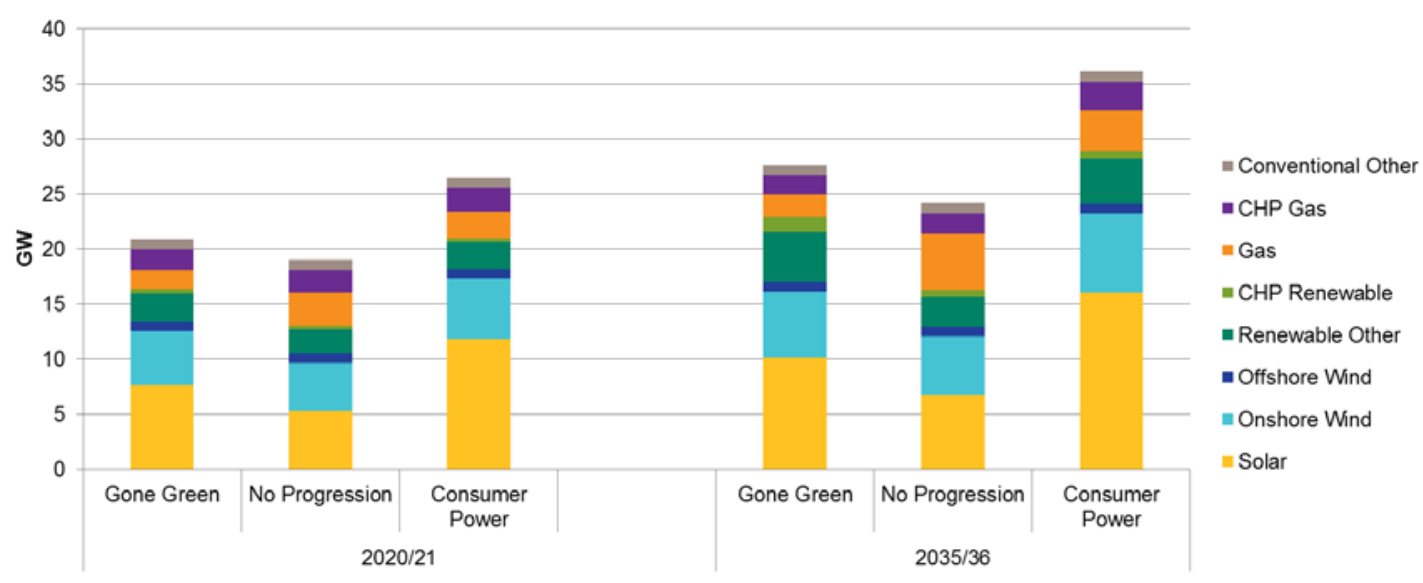

Figure 4. Scenarios for installed DG capacity

Source: Data from National Grid 2015a

\subsection{Policy Incentives for Renewable Deployment in the U.K.}

This section reviews the five policy schemes that have most impacted the U.K.'s rate of DG development: a renewable energy target, a FiT, the renewable obligation (RO) policy, contracts for differences (CfD), and a capacity market. The costs of FiT, RO, and CfD schemes are all managed through the Levy Control Framework, ${ }^{8}$ which sets annual limits on the overall costs these policies impose on consumers.

\subsubsection{Renewable Energy Targets}

Under the EU Renewable Energy Directive, the U.K. is legally bound to source $15 \%$ of its total energy demand from renewable sources by 2020 . While transportation has a specifically mandated $10 \%$ target, there are no specific targets for the electricity or heating sectors. Further, the Scottish government has introduced a target of $100 \%$ renewable electricity by 2020 and the Northern Ireland Executive has set a target of delivering 40\% renewable electricity by 2020 (DECC 2011). Even with these targets, National Grid, one of largest utilities in the U.K., has estimated that the country is likely to miss the 2020 target due to insufficient progress in the renewable heating and transport sectors. Renewables reached $24.6 \%$ of the country's electricity generation sector in 2015 (National Grid 2016; DECC 2016a).

\subsubsection{Feed-in Tariffs}

The U.K. adopted its FiT on April 1, 2010, and the policy is scheduled to expire in 2019. The FiT currently remunerates small-scale renewable and low-carbon generation technologies, including solar PV, wind, hydro of $5 \mathrm{MW}$ or less, and micro-CHP of $2 \mathrm{~kW}$ or less. The tariff is linked with the U.K.'s Real Prices Index so that it automatically adjusts with inflation.

By March 2016, 4.9 GW of DG capacity had been installed under the FiT, with DGPV accounting for $82 \%$ of that amount (DECC 2016b). Figure 5 shows the quarterly installed capacity by technology type registered under the FiT scheme since its implementation.

\footnotetext{
${ }^{8}$ For more information, see https://www.nao.org.uk/report/levy-control-framework-2/.
} 


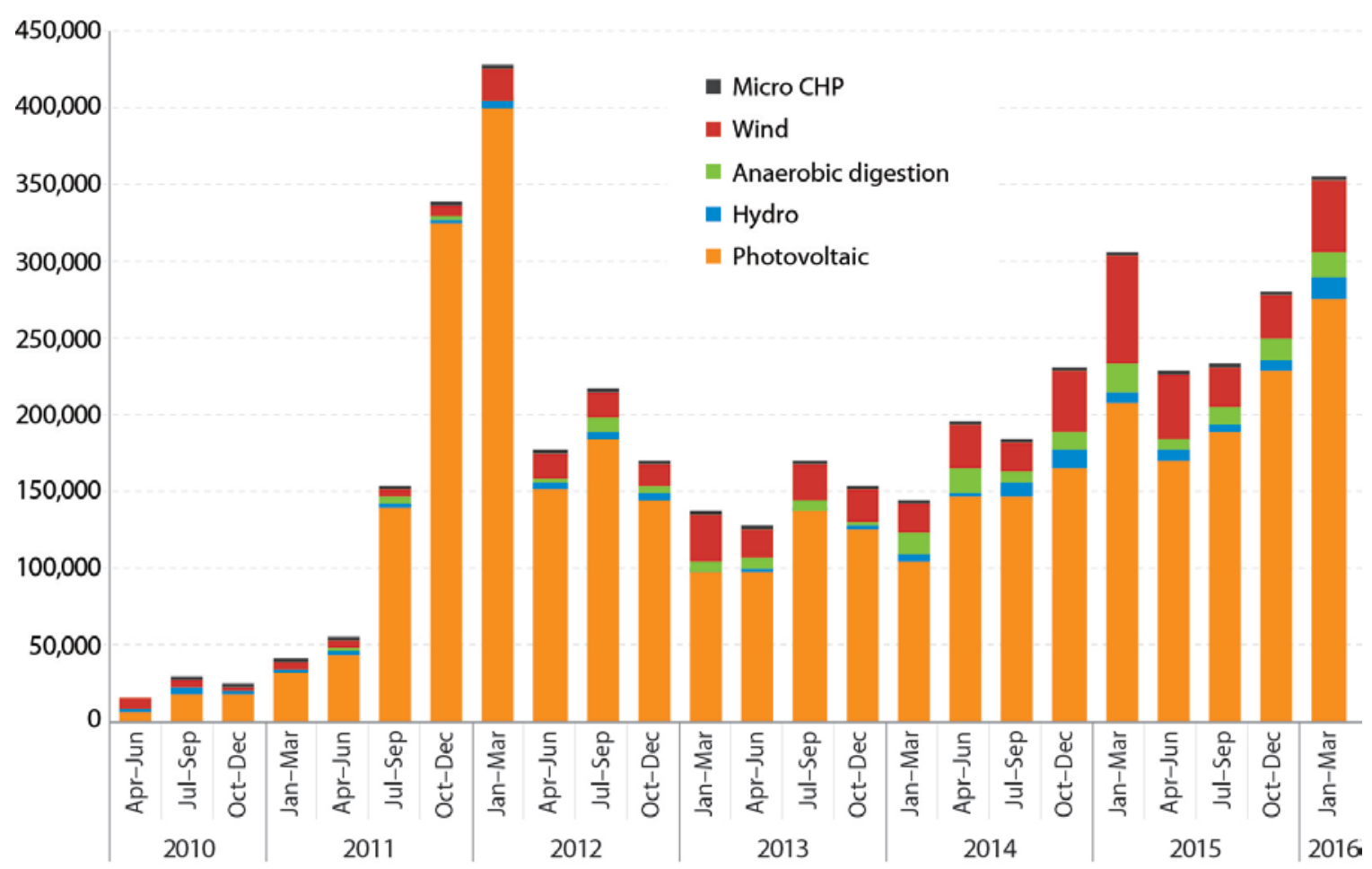

Figure 5. Quarterly installed capacity under FiT by technology type (MW)

Source: Data from Ofgem 2016b

As with other countries, the success of the U.K. FiT scheme has come at a cost. In 2015, the total bill for the scheme totaled $£ 866$ million (roughly $\$ 1.13$ billion USD), which, as in Germany, falls to electricity ratepayers via surcharges on the utility bill. In December 2015, the Department of Energy and Climate Change (DECC) announced changes to the scheme, including remuneration reductions of $58 \%-85 \%$ depending on the technology and system size, and a quarterly deployment cap for all technologies except micro-CHP (Ofgem 2016a). When the cap is reached for a certain technology type and size band, no further installations will receive the tariff rate until the next quarter and a degression of $10 \%$ (in addition to the default degression rate) is applied. This new FiT regime took effect on February 8, 2016, and new DG deployments have decreased since its adoption. DGPV installations were down 74\% year-over-year as of March 2016 (Ofgem 2016c).

\subsubsection{Renewable Obligations}

The RO scheme, introduced in 2002, provides incentives for the deployment of largescale ( $>5 \mathrm{MW}$ ) renewable electricity. The RO is scheduled to close to all new projects on March 31, 2017, when a CfD scheme takes effect (see Section 4.6). The RO has already closed for onshore wind and PV.

The RO scheme requires that a portion of all electricity supplied to consumers be met by renewable sources. Electricity suppliers can fulfill the RO by either presenting the required renewable obligation certificates (ROCs) or paying a set buyout price (essentially a penalty) per megawatt-hour for the shortfall. The buyout payment is distributed proportionally to suppliers who have submitted ROCs. This unique 
redistribution of buyouts in the U.K. RO scheme increases the value of ROC for the generators and encourages renewable energy generation (Zhou 2012).

The RO scheme has proceeded through two stages of development. From 2002 to 2009, one ROC was issued for each megawatt-hour of eligible renewable generation, regardless of the specific technology. This setup took a technology-neutral approach in order to minimize government intervention in markets and let competition drive down the costs. However, the approach was criticized for the financial risks to the renewable energy investors inherent in the RO design (Mitchell, Bauknecht, and Connor 2006; Klessmann Nabe, and Burgees 2008). In April 2009, banding was introduced to provide targeted support to different technologies based on costs and market readiness. Higher incentives were given to underdeveloped technologies, and the obligation was changed to a specified number of ROCs per 100 MWh of generation (Grimwood and Ares 2016). ${ }^{9}$ Guaranteed headroom was also introduced (i.e., the obligation is based on the expected renewable generation and an additional portion) to prevent a ROC price crash. Previously, if the RO target was met, the ROC price would fall to zero (Poyry 2006; Woodman and Mitchell 2011). In 2010, when the FiT was introduced, projects at or below $5 \mathrm{MW}$ could opt for either FiT remunerations or the RO scheme but not both.

The obligation has been raised from 0.097 ROCs/MWh in 2009-2010 (April 1 through March 31) to 0.348 ROCs/MWh in 2016-2017 (Ofgem 2016d). From 2014 to 2015, a total of 71.3 million ROCs were issued, representing $55.7 \mathrm{TWh}$ of renewable generation, which is equivalent to $18.6 \%$ of the U.K.'s total electricity supply (Ofgem 2016f).

\subsubsection{Contracts for Difference}

The U.K.'s Energy Act of 2013 established the legislative framework of electricity market reform, which aims to attract investment for generation capacity replacement and grid upgrade (DECC 2013). This legislation includes provisions for CfD, a capacity market, a carbon price floor, emissions performance standards, and other levers to grow renewables and rein in emissions. The CfD scheme has emerged as a major support mechanism for low carbon generation technologies and will be the successor to the RO when it expires in 2017.

A CfD is a financial instrument that offers generators a fixed price (known as the strike price) for their power output. In addition to the regular sales contract for its output, an eligible generator enters into a CfD with a counterparty owned by the government and funded by a levy on electricity suppliers. When the market price is lower than the CfD strike price, the generator receives a payment under the CfD that brings up the value per megawatt-hour to the strike price. If the market price is higher than the strike price, then the generator pays the difference to the counterparty for each megawatt-hour sold (DECC 2012). CfDs are awarded to generators through an allocation round, which is open to

\footnotetext{
${ }^{9}$ The methodology used in calculating the RO is described in DECC (2015). The Renewables Obligation for 2016/17: Calculating the Level of the Renewables Obligation for 2016/17. London: DECC. https://www.gov.uk/government/uploads/system/uploads/attachment data/file/464685/Renewables_Obligat ion_Level_Calculations_for_2016-17.pdf
} 
projects such as onshore and offshore wind, solar PV, and hydro of over $5 \mathrm{MW}$. Projects sized at or above $300 \mathrm{MW}$ require a government certification to be allocated a CfD.

The government sets a maximum strike price administratively for most technologies, but when CfDs are allocated via auction, the strike price is set by the winning bids (which are often lower than the administrative strike price) (Clifford Chance 2015).

While the CfD scheme is designed to reduce price risk, it has been criticized for affecting financial performance compared to the effects of an RO scheme. A recent study using detailed market simulation models (Bunn and Yusupov 2015) shows that as wind penetration grows, the correlation between the market clearing price and the wind generator output becomes increasingly negative. The implementation of the CfD scheme in the U.K. has had complications. The second round of allocations was delayed without an official statement, and there was uncertainty among the participants regarding whether the auction budget would be allocated in preference of less mature technologies.

Additionally, the budget for the 2016 auction has been cut by $11 \%$. Several consultations were conducted in 2016 on the CfD contract and regulations, non-delivery disincentives, and delivery year extension. These consultations reveal that U.K. developers continue to have reservations about the efficacy of the CfD mechanism (BNEF 2016c; Massie et al. 2016).

\subsubsection{Capacity Markets}

The U.K.'s electricity market reform established a voluntary, technology-neutral capacity market to ensure security of electricity supply. The capacity auctions are open to new and existing generation, as well as DR resources. Capacity below 2 MW can only participate when combined with other capacity into a "capacity market unit" (CMU) or through an aggregator. Low-carbon generators that are already receiving other forms of support, such as CfDs, are not eligible to participate in the capacity market, at least when the strike prices are set administratively (DECC 2014). When the 2015 capacity auction concluded in December 2015, 46.4 GW of capacity were awarded for delivery in 20192020 at the price of $£ 18 / \mathrm{kW} /$ year (National Grid 2015b). Even though many distributed and DR resources were prequalified for the auction, the majority of the clearing capacity has been combined-cycle gas turbines, nuclear, and coal or biomass generators (Ofgem 2016e). Some studies have shown that the capacity market may have been introduced prematurely in the U.K. and therefore created cost burdens on consumers without providing for renewable deployment (Baker, Bayer, and Raczka 2015; van der Burg and Whitley 2016).

\subsubsection{Regulation of Distribution Networks}

In addition to being affected by policies and incentives, DG growth in the U.K. has also been influenced by changes to the regulatory construct. Much like utilities in the United States (except those that have been decoupled), the U.K.'s distribution network operators' (DNOs) earnings prior to 2015 reforms were directly correlated to the amount of electricity they distributed and the number of customers they served. This provided a disincentive for DNOs to take any measure that might reduce demand (Ofgem 2009). In 2013, the U.K. Office of Gas and Electricity Markets (Ofgem) established the RIIO $($ Revenue $=$ Incentives + Innovation + Outputs $)$ framework for setting price controls for 
network companies, which effectively decouples demand from DNO earnings (Ofgem 2013). RIIO-ED1 applies to the electricity distribution networks and is effective from 2015 to 2023. The default price control period under RIIO is eight years, which provides greater innovation incentives by allowing companies to retain their cost savings for longer than under the previous regulatory regime (i.e., five years) (Lowry, Newton, and Woolf 2016). The RIIO scheme also ties a large portion of the utility's revenue to its performance outputs and an allowable return received on a percentage of the total expenditures rather than on simply capital investment. DG is embedded within the general performance-based framework, which includes incentives for six primary outputs: customer satisfaction, reliability and availability, safety, conditions for connection, environmental impact, and social obligations (Ofgem 2010).

Additional measures for stimulating innovation were also established with the RIIO regime; a Network Innovation Competition was set up to allow DNOs to compete for funding of up to $£ 81$ million per year for development and demonstration of new technologies. The Network Innovation Allowance provides a limited amount of use-it-orlose-it funding to DNOs for small technical, commercial, or operational projects (Ofgem 2016g; Ofgem 2016h). Some analysts argue that despite potential problems due to its complexity, RIIO is steering regulation in direction of a low-carbon economy (FoxPenner, Harris, and Hesmondhalgh 2013). RIIO has been criticized for offering few incentives for DNOs and transmission owners to expand storage applications. In fact, storage is "double charged" for using the transmission network due to the costs of both importing from and exporting to the grid (Lightsource 2015). 


\section{Australia}

\subsection{Distributed Generation: Development Status and Projections}

Australia has significantly increased its clean energy generation in response to electricity sector deregulation and environmental policies (Weimar et al. 2016). In 2015, renewable energy generation accounted for $14.6 \%$ of the national total with $35 \mathrm{TWh}$. Hydro accounted for $40.1 \%$ of renewable generation; wind and solar accounted for $33.7 \%$ and $17 \%$ respectively. Australia had over 1.5 million solar PV systems operating by the end of 2015, primarily at the residential and commercial scale with a capacity of less than $100 \mathrm{~kW}$; these systems accounted for over $16 \%$ of all households in Australia (see Figure 6) (Spector 2016; CEC 2016). The average system size for solar systems is about $5 \mathrm{~kW}$ nationally (CEC 2016).

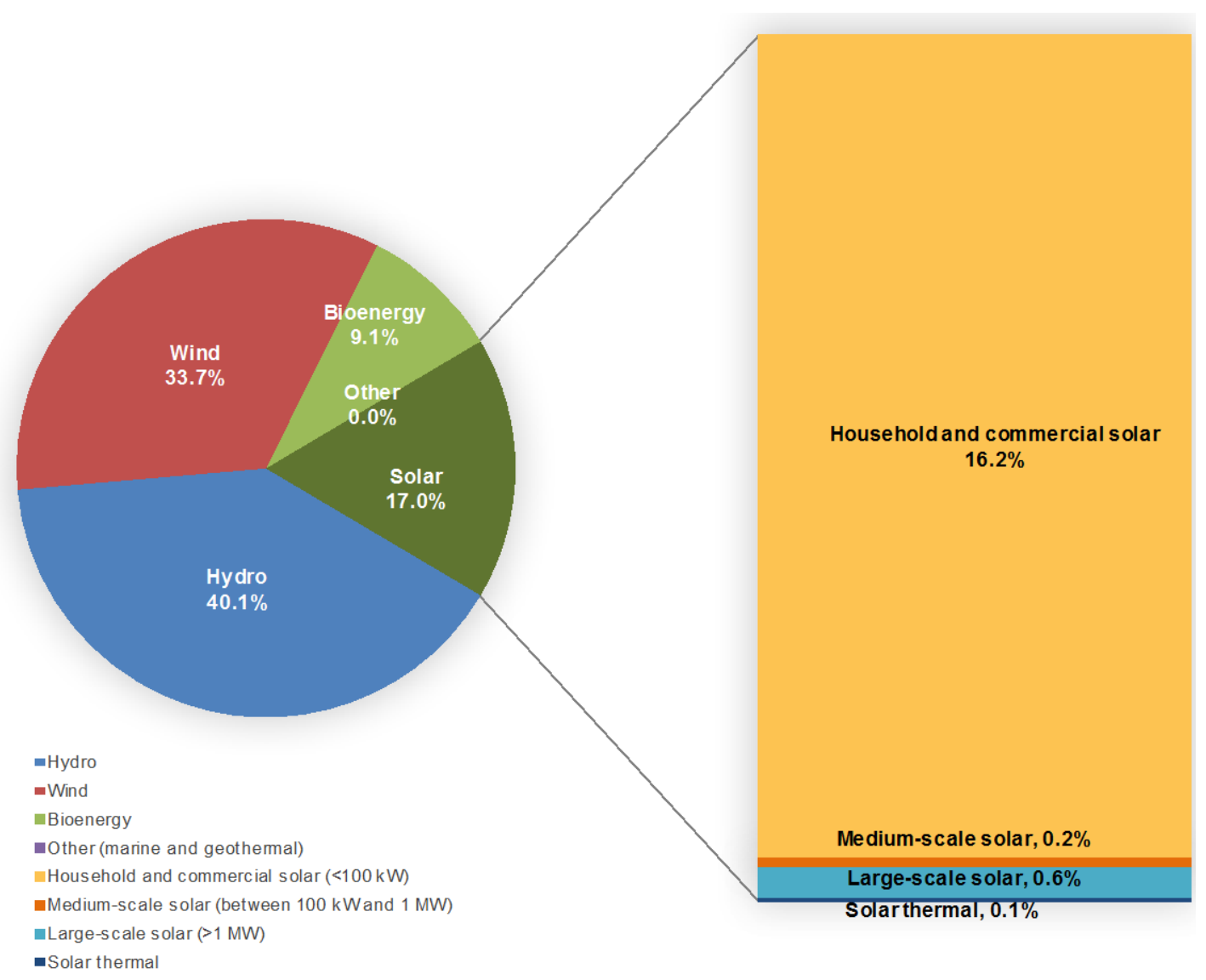

Source: CEC 2016

Figure 6. Australia renewable energy generation by technology in 2015 (percentage of total renewable generation) 
A suite of favorable policies, including rebates, state-level FiTs, a renewable energy certificate (REC) market, and a now defunct carbon tax, have fueled the rapid deployment of DGPV since 2008 (Sommerfeld et al. 2016). Recent shifts toward lower compensation levels for solar PV generation could give rise to the deployment of behindthe-meter energy storage in Australia (i.e., lower compensation for exported energy encourages self-consumption, which can drive demand for storage).

\subsection{National Programs: Rebates and Renewable Energy Targets}

In 2000, Australia issued the Mandatory Renewable Energy Target, requiring 9.5 TWh of renewable energy generation by 2010, with compliance demonstrated through renewable energy certificates (RECs). Regulated entities, which are usually electricity retailers, need to purchase and surrender RECs through the clean energy regulator. Concurrently, the federal government had also offered rebates for small-scale (1.5 kW or below in capacity) solar PV systems. Beginning in 2000, the Federal Photovoltaic Rebate Program offered up to AU\$4,000 in rebates to reduce the capital costs of small-scale systems. By 2007, the incentive was renamed the Solar Homes and Communities Program and the rebate per system was increased to AU $\$ 8,000$. The program experienced over-subscription, even after limiting the eligibility of the program to households with a taxable income of less than AU\$100,000 (Nelson, Simshauser, and Kelley 2011.) As applications continued to increase and government funding was exhausted, the Solar Homes and Communities Program ended in 2009.

The end of the rebate program coincided with expansion of the Mandatory Renewable Energy Target as the original target was met ahead of schedule in 2007. The new target of $45 \mathrm{TWh}$ of renewable energy generation by 2020 was designed to guarantee that $20 \%$ of the national electricity supply would come from renewable resources. The new Renewable Energy Target (RET) commenced in 2011 under a two-tiered system. It is divided into the Large-scale Renewable Energy Target (LRET) and the Small-scale Renewable Energy Target (SRET). The LRET established a target of $41 \mathrm{TWh}$ for projects over $100 \mathrm{~kW}$, while the SRET set subsidies for small-scale projects of $100 \mathrm{~kW}$ and below to support 4 TWh by 2020 to fulfill the RET target (Chapman et al. 2016). Each year the Clean Energy Regulator ${ }^{10}$ sets a small-scale technology percentage that informs liable entities how many small-scale technology certificates (STCs) they will need to purchase. The STC requirement is calculated in advance of the compliance year based on an estimate of the number of STCs that will be created in the year ahead.

For small-scale solar systems, STCs are based on the expected output of the solar system over a 15-year period. For each megawatt-hour of solar electricity generated, a Solar Credit Multiplier is applied to the first $1.5 \mathrm{~kW}$. This multiplier began at $5 \mathrm{X}$ (i.e., five times) and had a scheduled phase-down to zero at the end of 2016 (see Table 7). For example, a $1.5-\mathrm{kW}$ system that generates $1 \mathrm{MWh}$ would be compensated at five times the standard rate and would receive five STCs, which amounts to an estimated $\$ 5,000$ for a

\footnotetext{
${ }^{10}$ The Clean Energy Regulator, established in 2012, is an independent statutory authority under the Department of the Environment and Energy. It is responsible for administering legislation related to renewable energy and carbon emissions reduction goals. The Clean Energy Regulator accredits and allocates RECs.
} 
$1.5 \mathrm{~kW}$ system (Nelson et al. 2011) ${ }^{11}$. These STCs are then placed into the STC clearinghouse for regulated entities to purchase. $^{12}$

Table 7. Scheduled Solar Credit Multiplier Step-down Schedule

\begin{tabular}{|l|r|r|r|r|r|r|l|}
\hline Compliance Year & $\begin{array}{l}2009- \\
2010\end{array}$ & $\begin{array}{l}2010- \\
2011\end{array}$ & $\begin{array}{l}2011- \\
2012\end{array}$ & $\begin{array}{l}2012- \\
2013\end{array}$ & $\begin{array}{l}2013- \\
2014\end{array}$ & $\begin{array}{l}2015- \\
2016\end{array}$ & $\begin{array}{l}\text { Post } \\
2016\end{array}$ \\
\hline Solar credit multiplier & 5 & 5 & 5 & 4 & 3 & 2 & None \\
\hline
\end{tabular}

The Solar Credit Multiplier afforded up-front cost reduction for small solar system owners, but it caused overcapacity in the market and flooded the REC market with household solar thermal heaters and pumps, which received a subsidy from the government. This led to a steep decline in REC prices (as low as AU\$29/REC), and a resultant slackening in demand for solar instalations. As a result, the government amended the rules so that STCs are placed into the clearinghouse at a fixed price of AU\$40 (Chapman, McLellan, and Tezuka 2016).

Utility-scale wind projects have been the primary beneficiary of the RET, accounting for about $70 \%$ of registered RET generation from 2001 to 2015 , while solar accounted for about $4.6 \%$ of registered RET generation (Weimar et al. 2016). FiT policies, driven by states, have a more profound effect on DGPV in Australia (Chapman, McLellan, and Tezuka 2016). See Figure 7 for DGPV deployment in Australia since 2001, and Figure 8 for the policy suite that has contributed to this growth.

\footnotetext{
${ }^{11}$ While owners of small-scale solar systems can directly sell the STCs, in practice installers often offer an upfront discount or cash payment for the right to the STCs (Department of the Environment and Energy 2016).

${ }^{12}$ While owners of small-scale solar systems can directly sell the STCs, in practice installers often offer an upfront discount or cash payment for the right to the STCs (Department of the Environment and Energy 2016).
} 


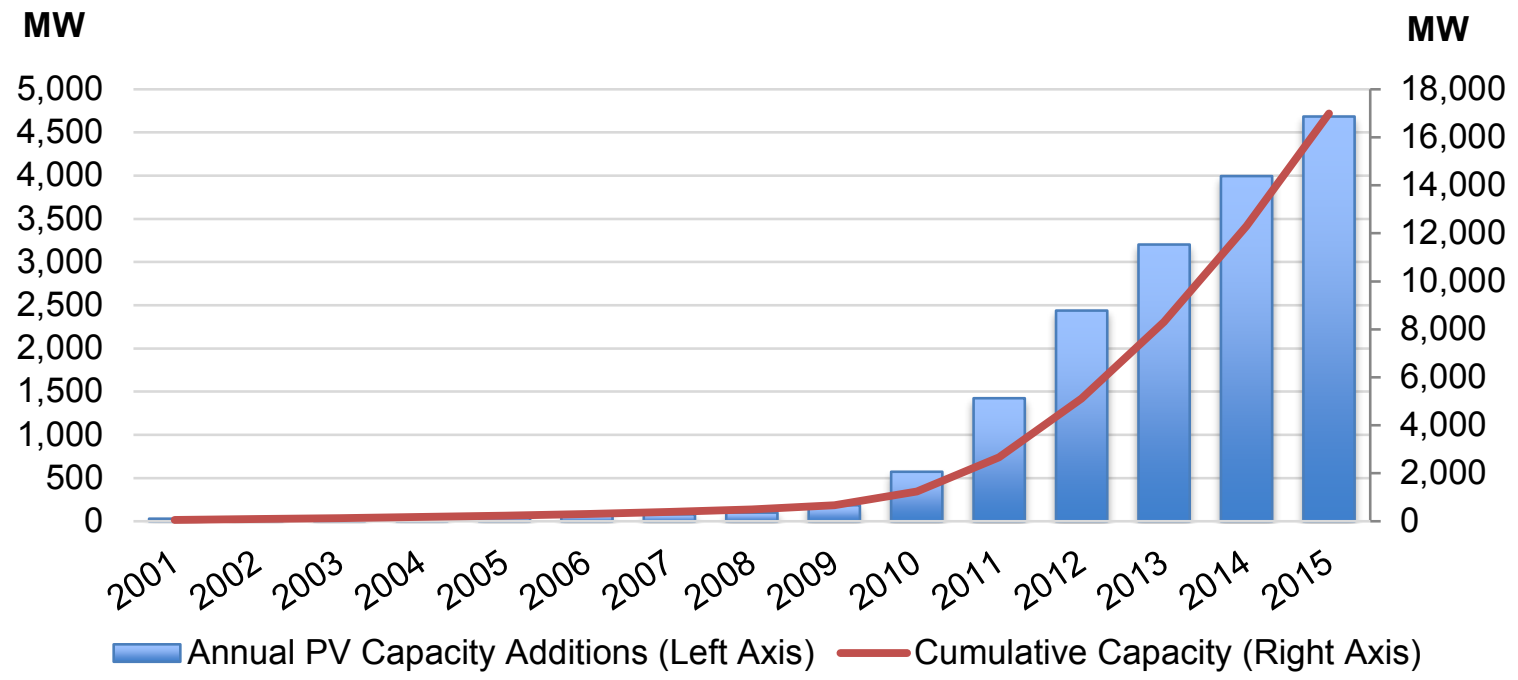

Figure 7. Annual and cumulative installed DGPV capacity in Australia, 2001-2015 Source: BNEF 2016d

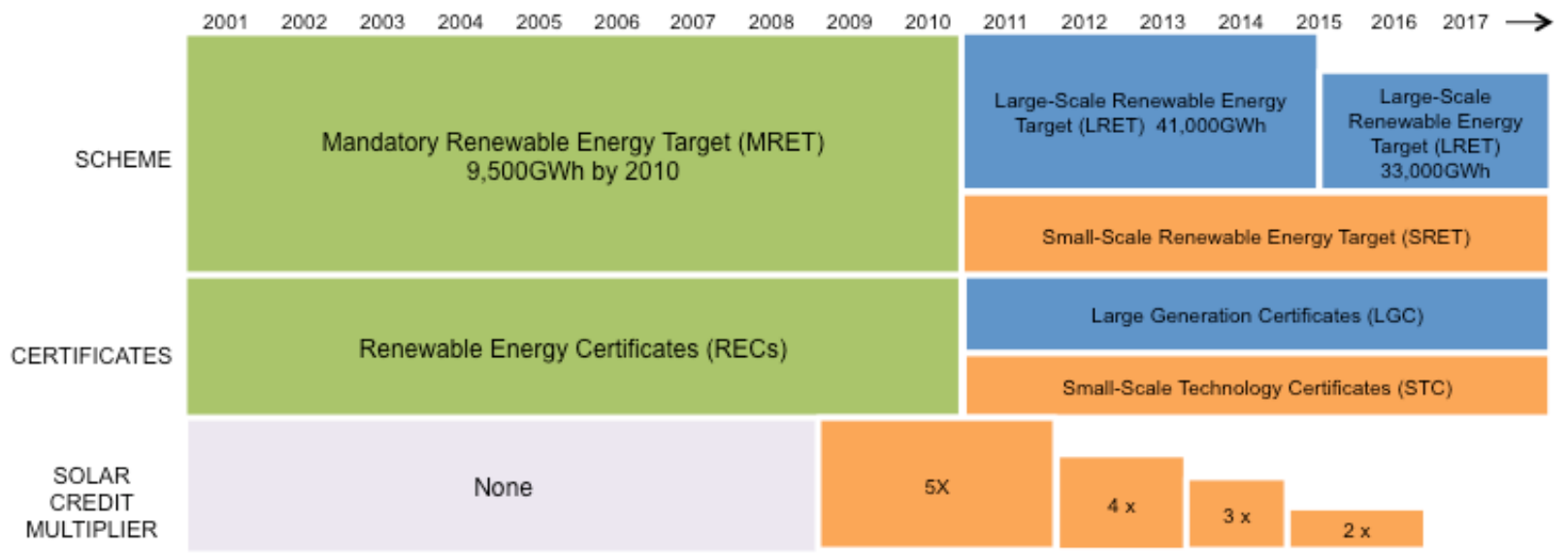

Figure 8. Summary of national level renewable energy policy in Australia

Adapted from Chapman, McLellan, and Tezuka 2016 


\subsection{State Programs: Feed-in Tariffs}

Most Australian states established high FiTs for small PV systems. States have established many FiT levels and structures, but most fall within one of two types: gross or net. A gross FiT compensates $100 \%$ of the electricity generated from renewables, without considerations for time of use; the system owner then pays the retail price for the electricity consumed. Under a net FiT scheme, solar generation is first used on site to offset electricity consumption; any excess energy exported to the grid is compensated at the net FiT rate. ${ }^{13}$

Most state FiTs started at a much higher rate than the retail electricity price. In 2012 and 2013, several states ended applications for the relatively high FiT incentives and transitioned to utility buy-back rates or retail rates for solar electricity exported to the grid. Several premium and/or transitional FiT schemes in South Australia, Victoria, and New South Wales are scheduled to end in 2016. Approximately 275,000 solar PV owners will experience a drop in FiT payment from AU\$0.16-0.60/kWh to AU\$0.05-0.07/kWh (Moyse, Carrazzo, and Reddaway 2016). Table 8 summarizes the FiT levels and schedules for Australian states and territories.

Although the state-level tariffs have already passed the most lucrative stages for new projects, existing projects in several states and territories will continue to receive premium FiT rates. For projects whose premium FiT is expiring, retail electricity companies can offer low prices for solar electricity and RECs at their discretion.

${ }^{13}$ In other case studies discussed in this report, Germany offered a gross FiT while the United Kingdom offered a generation tariff for electricity generated by renewables and a different rate for renewable electricity exported to the grid. 
Table 8. Summary of Australian States FiT Schemes (all prices in AU\$/kWh)

\begin{tabular}{|c|c|c|c|c|c|c|c|c|c|c|c|}
\hline & 2008 & 2009 & 2010 & 2011 & 2012 & 2013 & 2014 & 2015 & 2016 & $\begin{array}{l}\text { Premium FiT } \\
\text { end date }\end{array}$ & $\begin{array}{l}\text { Transitional and } \\
\text { standard FiT end date }\end{array}$ \\
\hline South Australia & $\begin{array}{l}0.44 \\
\text { net }\end{array}$ & $\begin{array}{l}0.44 \\
\text { net }\end{array}$ & $\begin{array}{l}0.44 \\
\text { net }\end{array}$ & $\begin{array}{l}0.44 \\
\text { net }\end{array}$ & 0.16 net & 0.16 net & $\begin{array}{l}0.06^{a} \\
\text { net }\end{array}$ & $\begin{array}{l}0.06 \\
\text { net }\end{array}$ & $\begin{array}{l}0.06 \\
\text { net }\end{array}$ & 2028 & $\begin{array}{l}2016 \text { for } 0.16 \\
\text { (transitional) }\end{array}$ \\
\hline $\begin{array}{l}\text { Western } \\
\text { Australia }\end{array}$ & - & - & $\begin{array}{l}0.40 \\
\text { net }\end{array}$ & $\begin{array}{l}0.20^{b} \\
\text { net }\end{array}$ & $\begin{array}{l}\text { BB } \\
\text { net }\end{array}$ & $\begin{array}{l}\text { BB } \\
\text { net }\end{array}$ & $\begin{array}{l}\text { BB } \\
\text { net }\end{array}$ & $\begin{array}{l}\text { BB } \\
\text { net }\end{array}$ & $\begin{array}{l}\text { BB } \\
\text { net }\end{array}$ & $\begin{array}{l}10 \text { years from } \\
\text { installation }\end{array}$ & No set date \\
\hline Tasmania & $\begin{array}{l}\mathrm{RR}^{\mathrm{c}} \\
\text { net }\end{array}$ & $\begin{array}{l}\mathrm{RR} \\
\text { net }\end{array}$ & $\begin{array}{l}\text { RR } \\
\text { net }\end{array}$ & $\begin{array}{l}\text { RR } \\
\text { net }\end{array}$ & RR net & $\begin{array}{l}\mathrm{RR} \\
\text { net }\end{array}$ & $\begin{array}{l}0.08 \\
\text { net }\end{array}$ & $\begin{array}{l}0.05 \\
\text { net }\end{array}$ & $\begin{array}{l}0.05 \\
\text { net }\end{array}$ & 2018 & No set date \\
\hline Victoria & - & $\begin{array}{l}0.60 \\
\text { net }\end{array}$ & $\begin{array}{l}0.60 \\
\text { net }\end{array}$ & $\begin{array}{l}0.60 \\
\text { net }\end{array}$ & $\begin{array}{l}0.25 \\
\text { net }\end{array}$ & $\begin{array}{l}\text { BB } \\
\text { net }\end{array}$ & $\begin{array}{l}\text { BB } \\
\text { net }\end{array}$ & BB net & $\begin{array}{l}\text { BB } \\
\text { net }\end{array}$ & 2024 & $\begin{array}{l}2016 \text { for } 0.25 \\
\text { (transitional) }\end{array}$ \\
\hline $\begin{array}{l}\text { New South } \\
\text { Wales }\end{array}$ & - & - & $\begin{array}{l}0.60 \\
\text { gross }\end{array}$ & 0.20 net & $\begin{array}{l}\text { BB } \\
\text { net }\end{array}$ & BB net & $\begin{array}{l}\text { BB } \\
\text { net }\end{array}$ & BB net & BB net & 2016 & $\begin{array}{l}2016 \text { for } 0.20 \\
\text { (transitional) }\end{array}$ \\
\hline $\begin{array}{l}\text { Australian } \\
\text { Capital Territory }\end{array}$ & - & $\begin{array}{l}0.50 \\
\text { gross }\end{array}$ & $\begin{array}{l}0.50 \\
\text { gross }\end{array}$ & $\begin{array}{l}0.46 \\
\text { gross }\end{array}$ & $\begin{array}{l}\text { BB } \\
\text { net }\end{array}$ & $\begin{array}{l}\text { BB } \\
\text { net }\end{array}$ & $\begin{array}{l}\text { BB } \\
\text { net }\end{array}$ & $\begin{array}{l}\text { BB } \\
\text { net }\end{array}$ & $\begin{array}{l}\text { BB } \\
\text { net }\end{array}$ & $\begin{array}{l}20 \text { years from } \\
\text { installation }\end{array}$ & No set date \\
\hline Queensland & $\begin{array}{l}0.44 \\
\text { net }\end{array}$ & $\begin{array}{l}0.44 \\
\text { net }\end{array}$ & $\begin{array}{l}0.44 \\
\text { net }\end{array}$ & $\begin{array}{l}0.44 \\
\text { net }\end{array}$ & $\begin{array}{l}0.08 \\
\text { net }\end{array}$ & $\begin{array}{l}0.08 \\
\text { net }\end{array}$ & $\begin{array}{l}0.08^{b} \\
\text { net }\end{array}$ & 0.06 net & $\begin{array}{l}0.07 \\
\text { net }\end{array}$ & 2028 & $\begin{array}{l}2014 \text { for } 0.08 \\
\text { (transitional) }\end{array}$ \\
\hline FiT types: & \multicolumn{2}{|c|}{ Premium } & \multicolumn{2}{|c|}{ Transitional } & Basic & & & & & & \\
\hline
\end{tabular}

The years indicate end date for application of the incentives.

BB indicates the rate under the utility buy-back scheme determined by utilities.

$\mathrm{RR}$ indicates the retail rate. The average residential retail rate in Tasmania in 2008-2009 was approximately AU $\$ 0.16 / \mathrm{kWh}$. It increased to approximately AU $\$ 0.25 / k W h$ in 2013-2014 (BNEF 2016d).

a The minimum retailer payment in South Australia is AU $\$ 0.068 / \mathrm{kWh}$ as determined by the Essential Services Commission of South Australia. Customers receiving the FiT are also eligible for the minimum retailer payment as an added incentive.

${ }^{b}$ Customers who applied for the incentive before July 1, 2011 receive a FiT of AU $\$ 0.4 / k W h$. Customers who applied for the incentive after July 1,2011 and before August 1, 2011 receive AU $\$ 0.2 / \mathrm{kWh}$.

c Tasmania's retail tariff rate is offered through Aurora Energy under a voluntary solar purchase program. The rate was equivalent to the retail rate before September 2013, and it drops to a government-regulated rate of AU $\$ 0.05-0.07 / \mathrm{kWh}$.

${ }^{c}$ The feed-in tariff rate in Southeastern Queensland was deregulated in 2014 , and it is now determined by retailers. The regional areas follow a minimum rate set by the regulator annually upon review. 


\subsection{Storage}

The changes to solar tariffs could lead to increased demand for end-user battery storage. As higher FiT options run out, energy storage may bring more value to a residential or commercial solar owner, particularly as the cost of batteries declines. Solar PV plus storage can reduce the amount of electricity purchased from the grid, which costs three to five times more than the standard export feed-in tariffs received from utilities. Storage also allows solar generation to be used during peak periods in the evening.

The Australian Renewable Energy Agency (ARENA) is supporting several pilot projects, the largest of which is planned by AGL, a large energy retailer. Plans for the AU\$20 million project, with AU $\$ 5$ million committed by ARENA, are to install 1,000 centrally controlled batteries in South Australia using energy storage systems with a combined capacity of $5 \mathrm{MW} / 7 \mathrm{MWh}$ (ARENA 2016).

While Australia does not have a national subsidy program for distributed energy storage, several subnational programs have emerged. The Australian Capital Territory government plans to finance $36 \mathrm{MW}$ of distributed battery storage in more than 5,000 homes by 2020 (Environment, Planning and Sustainable Development Directorate 2016). The City of Adelaide offers up to AU \$5,000 per system for 50\% of installed energy storage system cost.

Despite having relatively favorable conditions for PV plus storage, the solar PV plus storage market in Australia is in the beginning stages of development. However, with high retail electricity prices, the declining FiT, a decline in battery storage costs, and the availability of innovative electricity tariff structures, the market is projected to grow even in the absence of favorable direct subsidies for battery storage systems. The Australian Energy Market Operator ${ }^{14}$ forecasts that the installed capacity for new rooftop PV plus storage systems will increase to 529 MWh by 2017-2018 and to 3,445 MWh by 2024$2025^{15}$ (AEMO 2015).

\footnotetext{
${ }^{14}$ The Australian Energy Market Operator-which began operations in 2009 and manages the National Electricity Market and the Victorian gas transmission network - is responsible for national transmission planning for electricity and it establishes the short-term trading market for gas.

${ }^{15}$ The forecast focuses on installation of batteries as part of new PV installations. It does not consider the economics of retrofitting battery storage to existing rooftop PV. The assumptions do not include subsidies for storage in addition to existing mechanisms or programs.
} 


\section{Conclusion}

National and subnational governments in countries with significant DGPV penetration are transitioning to more market-based solutions from the high-cost direct support mechanisms (e.g., feed-in tariffs) and so-called "blunt instruments" (NEM) that have hitherto incentivized growth and driven cost reductions. These market-based approaches include (1) altering the utility regulatory landscape to provide DG resources with an efficient market structure (as in California and New York), (2) requiring DGPV to bid its generation into the energy markets and competitive auctions for capacity (as in Germany), and (3) implementing CfD schemes that act as price stabilizers. The effect of these transitions in all three countries has generally been a deceleration in the pace of capacity additions, and it remains to be seen whether sustainable growth can and will proceed from this point.

DG technologies, in general, can provide solutions to some of the challenges that high PV penetration levels have introduced. For example, storage can smooth PV's generation profile, flatten system required ramp rates when the sun goes down, allow solar to provide grid services such as frequency and voltage control, and diminish the necessity for NEM in calculating payback. In this sense, PV has laid the foundations and created the demand for the growth of other DG resources going forward. It remains to be seen how these various technologies will integrate with each other, the business models that develop around these technology bundles and energy management services, and the regulatory, policy, and market infrastructure that will support further DG deployment. But in the interim, governments, regulators, industry, and other stakeholders are racing to put these necessary systems in place as technologies, consumer preferences, environmental constraints, and other macro factors force a reimagining of the electricity grid. 


\section{References}

AEMO (Australian Energy Market Operator). 2015. Emerging Technologies Information Paper-National Electricity Forecasting Report. Australian Energy Market Operator Ltd. Accessed November 20, 2016: https:/www.aemo.com.au/-/media/Files/PDF/EmergingTechnologies-Information-Paper.pdf.

Anand, Mohit. 2016. Global Solar Demand Monitor Q3 2016. Greentech Media Research. Accessed October 2016.

ARENA (Australian Renewable Energy Agency). 2016. Battery Storage Set to Strengthen South Australian Grid - Australian Renewable Energy Agency. Australian Renewable Energy Agency. August 5, 2016. Accessed December 7, 2016: http://arena.gov.au/media/battery-storage-set-strengthen-south-australian-grid/.

Baker, Phil, Edith Bayer, and Jan Raczka. 2015. Capacity Market Arrangements in Great Britain. Warsaw: Forum for Energy Analysis.

Bird, Lori, Carolyn Davidson, Joyce McLaren, and John Miller. 2015. Impact of Rate Design Alternatives on Residential Solar Customer Bills: Increased Fixed Charges, Minimum Bills, and Demand-Based Rates. Golden, CO: National Renewable Energy Laboratory. NREL/TP-6A20-64850. http://www.nrel.gov/docs/fy15osti/64850.pdf.

Bird, L., J. McLaren, J. Heeter, C. Linvill, J. Shenot, R. Sedano, and J. MigdenOstrander. 2013. Regulatory Considerations Associated with the Expanded Adoption of Distributed Solar. Golden, CO: National Renewable Energy Laboratory. NREL/TP6A20-60613. http://www.nrel.gov/docs/fy14osti/60613.pdf.

BNEF (Bloomberg New Energy Finance). 2016a. Germany. New York: Bloomberg New Energy Finance.

\section{Energy Finance.}

—. 2016c. "UK EMR - Contract for Differences (CfD)." Accessed August 2016: https://www.bnef.com/policy/1069.

\section{—. 2016d. Australia. New York: Bloomberg New Energy Finance.}

Bunn, Derek, and Tim Yusupov. 2016. "The Progressive Inefficiency of Replacing Renewable Obligation Certificates with Contracts-for-Differences in the UK Electricity Market." Energy Policy 82: 298-309.

Burgess, Andy. 2015. "Responding to the Growth of DG: The Network Challenge." Presentation at the Distributed Generation Forum on September 15, 2015. London: Office of Gas and Electricity Markets. 
CEC (Clean Energy Council). 2016. Clean Energy Australia Report 2015.

https://www.cleanenergycouncil.org.au/dam/cec/policy-and-

advocacy/reports/2016/clean-energy-australia-report-2015.pdf.

CER (Clean Energy Regulator). 2016a. "The Renewable Energy Target Explained" http://www.cleanenergyregulator.gov.au/About/Accountability-and-

reporting/administrative-reports/The-Renewable-Energy-Target-2012-Administrative-

Report/The-Renewable-Energy-Target-explained.

—. 2016b. "REC Registry Summary Holdings." Accessed February 29, 2016:

https://www.rec-registry.gov.au/rec-registry/app/public/summary-holdings.

Chapman, Andrew J., Benjamin McLellan, and Tetsuo Tezuka. 2016. "Residential Solar PV policy: An Analysis of Impacts, Successes and Failures in the Australian Case."

Renewable Energy 86(February 2016). http://ac.els-cdn.com/S0960148115303402/1s2.0-S0960148115303402-main.pdf? tid=95972880-86d4-11e6-aa9c00000aab0f6b\&acdnat $=1475216008$ fe2c74a9d5237f67c951700e46cbe487.

Clean Energy Wire. 2016. https://www.cleanenergywire.org/news/germany-set-missclimate-goals-think-tank/eeg-surcharge-2017.

Clifford Chance. 2015. "Briefing Note: Contracts for Difference: An EMR CfD Primer." https://www.cliffordchance.com/briefings/2015/10/contracts_for_differenceanemrcfdpri mer.html.

CPUC (California Public Utilities Commission). 2016a. Decision Revising the SelfGeneration Incentive Program Pursuant to Senate Bill 861, Assembly Bill 1478, and Implementing Other Changes. Decision 16-06-055. Accessed October 2016: http://docs.cpuc.ca.gov/PublishedDocs/Published/G000/M163/K928/163928075.PDF.

—. 2016b. "Demand Response." Accessed November 2016:

http://www.cpuc.ca.gov/General.aspx?id=5924.

_. 2016c. "Distribution Resource Plan (R. 14-08-013)." Accessed November 2016 : http://www.cpuc.ca.gov/General.aspx?id=5071.

Darghouth, Naïm R., R. Wiser, Galen Barbose, and Andrew Mills. 2015. Net Metering and Market Feedback Loops: Exploring the Impact of Retail Rate Design on Distributed $P V$ Deployment. Berkeley, CA: Lawrence Berkeley National Laboratory. https://emp.lbl.gov/sites/all/files/lbnl-183185_1.pdf.

DECC (Department of Energy \& Climate Change). 2011. UK Renewable Energy Roadmap. London: DECC. https://www.gov.uk/government/uploads/system/uploads/attachment_data/file/48128/216 7-uk-renewable-energy-roadmap.pdf. 
_ 2012. Electricity Market Reform: Policy Overview. London: DECC. https://www.gov.uk/government/uploads/system/uploads/attachment_data/file/48371/534 9-electricity-market-reform-policy-overview.pdf.

—. 2013. "The Energy Act Received Royal Assent on 18 December 2013." News release, December 18. https://www.gov.uk/government/collections/energy-act.

_. 2014. Implementing Electricity Market Reform (EMR). London: DECC. https://www.gov.uk/government/uploads/system/uploads/attachment_data/file/324176/Im plementing_Electricity_Market_Reform.pdf.

_. 2016a. "UK Energy Statistics, 2015 \& Q4 2015.” Statistical press release. London: DECC.

https://www.gov.uk/government/uploads/system/uploads/attachment_data/file/513244/Pr ess_Notice_March_2016.pdf.

_ 2016b. Energy Trends Section 6: Renewables. London: DECC.

https://www.gov.uk/government/uploads/system/uploads/attachment_data/file/532907/Se ction 6.pdf.

Dehamna, A., A. Eller, and W. Tokash. 2016. Five Trends for Energy Storage in 2016 and Beyond. Navigant Research. Accessed October 2016.

Department of the Environment and Energy. 2016. "The Renewable Energy Target (RET) Scheme." Accessed December 5, 2016: http://www.environment.gov.au/climatechange/renewable-energy-target-scheme.

Energy UK. 2016. Pathways for the GB Electricity Sector to 2030. London: Energy UK. https://www.energy-uk.org.uk/publication.html?task=file.download\&id=5722.

Enkhardt, Sandra. 2015. "No German FiT Degression in Q4 for First Time." $P V$ Magazine. Accessed October 2016: http://www.pv-

magazine.com/news/details/beitrag/no-german-fit-degression-in-q4-for-firsttime $100021325 /$ \#axzz4LTwrHUQQ.

—. 2016. "Germany's Fifth Solar Auction Allocates $130 \mathrm{MW}$ to 25 Projects." $P V$ Magazine. Accessed October 2016: http://www.pvmagazine.com/news/details/beitrag/germanys-fifth-solar-auction-allocates-130-mw-to25-projects_100025687/\#axzz4RbT5OS1B.

Environment, Planning and Sustainable Development Directorate. 2016. "Next Generation Renewables." Australian Capital Territory Government. Accessed December 7, 2016. http://www.environment.act.gov.au/energy/cleaner-energy/next-generationrenewables.

EQ Research. 2016. State Bulletin: General Utility Rate Case Update, Q3 2016 Visualized. Greentech Media. Accessed November 2016. 
EU Tracking Roadmap. 2015. EU Tracking Roadmap 2015. Accessed November 2016: http://www.keepontrack.eu/publications.

FERC (Federal Energy Regulatory Commission). 2016. Order 155 FERC \ 61,229 Accepting Proposed Tariff Revisions Subject to Condition. Accessed November, 2016: https://www.ferc.gov/CalendarFiles/20160602164336-ER16-1085-000.pdf.

Fox-Penner, Peter, Dan Harris, and Serena Hesmondhalgh. 2013. "A Trip to RIIO in Your Future - Great Britain's Latest Innovation in Grid Regulation.” Public Utilities Fortnightly. October.

Gailfuß, Markus. 2016. "CHP Act 2016 - Summary of Regulations within the New CHP Act.” BHKW Infozentrum. Accessed October 2016: https://www.bhkwinfozentrum.de/rechtliche-rahmenbedingungen-bhkw-kwk/chp-act-2016-summary-ofregulations-within-the-new-chp-act.html.

Grimwood, Gabrielle Garton, and Elena Ares. 2016. Energy: The Renewables Obligation. London: House of Commons Library. Briefing paper. Number 05870.

Heinrich Böll Foundation. 2016. Energy Transition: The German Energiewende. Accessed September 2016: http://energytransition.de.

Hoff, Sara. 2016. "Germany's Renewables Electricity Generation Grows in 2015, but Coal Still Dominant." Today in Energy, May 24.

http://www.eia.gov/todayinenergy/detail.php?id=26372.

Joint Utilities of New York. 2016. Supplemental Distributed System Implementation Plan. Case 16-M-0411: In the Matter of Distributed System Implementation Plans. Accessed November 2016: http://jointutilitiesofny.org/wpcontent/uploads/2016/10/3A80BFC9-CBD4-4DFD-AE62-831271013816.pdf.

Kann, Shayle. 2016. "How to Find a Compromise on Net Metering." Greentech Media. Accessed October 2016: https://www.greentechmedia.com/articles/read/how-to-findcompromise-on-net-metering.

Klessmann, C., Nabe, C., Burgees, K. 2008. "Pros and Cons of Exposing Renewables to Electricity Market Risks: A Comparison of the Market Integration Approaches in Germany, Spain and the UK.” Energy Policy 3: 3646-3661.

Lightsource, Good Energy, Foresight Group. 2015. The Decentralised Energy Transition. London: Lightsource Renewable Energy. http://www.solar-trade.org.uk/wpcontent/uploads/2015/10/20151020-Decentralised-Energy-FINAL.pdf.

Lowder, Travis, Paul Schwabe, Ella Zhou, and Douglas J. Arent. 2015. Historical and Current U.S. Strategies for Booting Distributed Generation. NREL/TP-6A20-64843.

Golden, CO: National Renewable Energy Laboratory. http://www.nrel.gov/docs/fy16osti/64843.pdf. 
Lowry, Mark Newton, and Tim Woolf. 2016. Performance-Based Regulation in a High Distributed Energy Resource Future. Berkeley, CA: LBNL. LBNL-1004130.

MDPT (Market Design and Platform Technology Working Group). 2015. Report on the Market Design and Platform Technology Working Group. Accessed October 2016: https://newyorkrevworkinggroups.com/wp-content/uploads/MDPTReport_150817_Final.pdf.

Massie, Kirsti, and Katy Norman. 2016. UK Electricity Market Reform: How Far Have We Come? London: White \& Case LLP.

Mitchell, C., D. Bauknecht, D., and P.M. Connor. 2006. "Effectiveness through Risk Reduction: A Comparison of the Renewable Obligation in England and Wales and the Feed-In System in Germany." Energy Policy 34: 297-305.

Moyse, Damien, Nick Carrazzo, and Andrew Reddaway. 2016. Life after FiT. Melbourne, VIC: Alternative Technology Association. http://www.ata.org.au/wpcontent/projects/TEC_Life_After_FiTs_Report_2016_summary.pdf.

NARUC (National Association of Regulatory Utility Commissioners). 2016. Distributed Energy Resources Rate Design and Compensation. Accessed November 2016: http://pubs.naruc.org/pub/19FDF48B-AA57-5160-DBA1-BE2E9C2F7EA0.

National Grid. 2015a. Future Energy Scenarios: UK Gas and Electricity Transmission. Warwick, England: National Grid.

_. 2015b. Final Auction Results: T-4 Capacity Market Auction for 2019/20. London: National Grid.

- 2016. Future Energy Scenarios: UK Gas and Electricity Transmission. Warwick, England: National Grid.

Nelson, Tim, Paul Simshauser, and Simon Kelley. 2011. "Australian Residential Solar Feed-in Tariffs: Industry Stimulus or Regressive form of Taxation?" Economic Analysis and Policy 41(2). http://www.sciencedirect.com/science/article/pii/S0313592611500153.

NYPSC (New York Public Service Commission). 2016. Case 15-E-0751 - In the Matter of the Value of Distributed Energy Resources. Staff Report and Recommendations in the Value of Distributed Energy Resources Proceeding. Accessed November 2016: http://documents.dps.ny.gov/public/Common/ViewDoc.aspx?DocRefId=\{59B620E687C4-4C80-8BEC-E15BB6E0545E\}.

\footnotetext{
- 2015. Case 14-M-0101 - Proceeding on Motion of the Commission in Regard to Reforming the Energy Vision. Staff White Paper on Ratemaking And Utility Business Models. Accessed November 2016: http://documents.dps.ny.gov/public/Common/ViewDoc.aspx?DocRefId $=\{48954621$ 2BE8-40A8-903E-41D2AD268798\}.
} 
Ofgem (Office of Gas and Electricity Market). 2005. The Innovation Funding Incentive \& Registered Power Zones Annual Reports - 2005/6. London: Ofgem.

http://webarchive.nationalarchives.gov.uk/20130402174434/http://www.ofgem.gov.uk/N etworks/Techn/NetwrkSupp/Innovat/ifi/Documents1/14908-Internetpage.pdf.

- 2009. History of Energy Network Regulation. London: Ofgem.

- 2010. Handbook for Implementing the RIIO Model. London: Ofgem. https://www.ofgem.gov.uk/ofgem-publications/51871/riiohandbook.pdf.

- 2013. Strategy Decision for the RIIO-ED1 Electricity Distribution Price Control: Outputs, Incentives and Innovation. London: Ofgem.

_. 2016a. "FiT Tariff Rates." Accessed August 8, 2016: https://www.ofgem.gov.uk/environmental-programmes/fit/fit-tariff-rates.

- 2016b. "Feed-in Tariffs: Quarterly Statistics." Accessed August 8, 2016: https://www.ofgem.gov.uk/environmental-programmes/fit/contacts-guidance-andresources/public-reports-and-data-fit/feed-tariffs-quarterly-statistics.

—. 2016c. "Feed-in Tariff Installation Report 31 March 2016." Accessed August 8, 2016: https://www.ofgem.gov.uk/publications-and-updates/feed-tariff-installation-report31-march-2016.

- 2016d. "Renewables Obligation (RO) Buy-Out Price and Mutualisation Ceilings for 2016-17." Accessed August 8, 2016: https://www.ofgem.gov.uk/publications-andupdates/renewables-obligation-ro-buy-out-price-and-mutualisation-ceilings-2016-17.

—. 2016f. Renewables Obligation Annual Report: 2014-15. London: Ofgem. https://www.ofgem.gov.uk/system/files/docs/2016/03/renewables_obligation_annual_rep ort 2014-15.pdf.

_. 2016g. "Electricity Network Innovation Competition." Accessed October 15, 2016: https://www.ofgem.gov.uk/network-regulation-riio-model/networkinnovation/electricity-network-innovation-competition.

- 2016h. "Electricity Network Innovation Allowance.” Accessed October 15, 2016: https://www.ofgem.gov.uk/network-regulation-riio-model/networkinnovation/electricity-network-innovation-allowance.

- 2016e. Annual Report on the Operation of the Capacity Market in 2015. London: Ofgem.

https://www.ofgem.gov.uk/system/files/docs/2016/06/annual_report_on the operation_o f the capacity market 6 june 2016 final.pdf.

Orme, Byron. 2016. Incapacitated: Why the Capacity Market for Electricity Generation is Not Working, and How to Reform It. London: Institute for Public Policy Research. 
Payne, Heather. 2015. "RIIO to REV: What U.S. Power Reform Should Learn from the U.K." Pace Law Review 31.

PG\&E (Pacific Gas and Electric). 2016. "Electric Vehicle (EV) Rate Plans: Making Sense of the Rates." Accessed September 2016:

https://www.pge.com/en US/residential/rate-plans/rate-plan-options/electric-vehiclebase-plan/electric-vehicle-base-plan.page.

Poudineh, Rahmatallah, and Tooraj Jamasb. 2014. "Distributed Generation, Storage, Demand Response, and Energy Efficiency as Alternatives to Grid Capacity Enhancement." Energy Policy 67:222-231.

Poyry. 2006. Creating Ski Slopes from Cliff-Edges: Removing Volume Risk from the Renewables Obligation. Poyry Energy Consulting. http://www.poyry.co.uk/sites/www.poyry.uk/files/SkiSlopesFromCliffEdges.pdf.

Proudlove, Autumn, Kate Daniel, Brian Lips, David Sarkisian, and Achyut Shrestha. 2016. 50 States of Solar: Q2 2016 Quarterly Report. NC Clean Energy Technology Center.

PV Grid. 2014. "National Updates: Germany.” Accessed October 2016: http://www.pvgrid.eu/national-updates/germany.html.

REV (Reforming the Energy Vision). 2016. Reforming the Energy Vision: REV. Accessed October 2016: https:/www.ny.gov/sites/ny.gov/files/atoms/files/WhitePaperREVMarch2016.pdf.

RMI (Rocky Mountain Institute). 2013. A Review of Solar PV Benefit \& Cost Studies. 2nd Ed. Accessed November 2016: http://www.rmi.org/elab empower.

Roselund, Christian. 2016. "Energy Storage Moves Front and Center under California's SGIP.” PV Magazine. Accessed November 2016: http://www.pvmagazine.com/news/details/beitrag/energy-storage-moves-front-and-center-undercalifornias-sgip_100025164/\#axzz4RbT5OS1B.

Roth, Sammy. 2015. “California Electricity Rates: Here's What Happens Next." The Desert Sun. Accessed October 2016:

http://www.desertsun.com/story/tech/science/energy/2015/07/07/california-electricityrates-heres-what-happens-next/29796489/.

Savenije, Davide. 2015. "In New York, Utility of the Future will be 'Air Traffic Controller'. Utility Dive. Accessed October 2016: http://www.utilitydive.com/news/innew-york-utility-of-the-future-will-be-air-traffic-controller/373342/. 
SEIA (Solar Energy Industries Association). 2016. Rate Design for a Distributed Grid: Recommendations for Electric Rate Design in the Era of Distributed Generation.

Accessed November 2016:

http://www.seia.org/sites/default/files/resources/Rate_Design_for_Distributed\%20Grid_8 -11-2016 FINAL.pdf.

Shah, Chandra. 2014. Net Metering. U.S. Department of Energy. Accessed November 2016: http://energy.gov/sites/prod/files/2014/05/f15/fupwg_may2014_net_metering.pdf.

Sommerfeld, Jeff, Laurie Buys, Kerrie Mengersen, and Desley Vine. 2016. "Influence of Demographic Variables on Uptake of Domestic Solar Photovoltaic Technology." Renewable and Sustainable Energy Reviews 67(January 2017):315-323. http://ac.elscdn.com/S1364032116305032/1-s2.0-S1364032116305032-main.pdf? tid=8970934a$\underline{86 \mathrm{~d} 2-11 \mathrm{e} 6-\mathrm{b} 9 \mathrm{dd}-}$ 00000aacb35d\&acdnat $=1475215128921502 \mathrm{e} 72490 \mathrm{bclef} 422 \mathrm{~b} 8 \mathrm{bd} 01 \mathrm{fec} 04 \mathrm{e}$.

Spector, Julian. 2016. "Why the Australian Solar-Plus-Storage Market Looks So Bright." Greentech Media. Accessed September 2016:

https://www.greentechmedia.com/squared/read/Why-the-Australian-Solar-Plus-StorageMarket-Looks-So-Bright.

St. John, Jeff. 2015a. "SDG\&E Proposes a 'Bring-Your-Own-Battery Tariff." Greentech Media. Accessed October 2016: http://www.greentechmedia.com/articles/read/sdgesproposes-a-bring-your-own-battery-tariff.

- 2015b. "The Details behind California's Demand Response Auction Mechanism. Greentech Media. Accessed October 2016:

https://www.greentechmedia.com/articles/read/The-Details-Behinds-CaliforniasDemand-Response-Auction-Mechanism.

_. 2015c. "California Launches Its First Real-World Smart Inverter Test." Greentech Media. Accessed October 2016:

https://www.greentechmedia.com/articles/read/california-launches-its-first-real-worldsmart-inverter-test.

Taylor, Mike. 2016. Will Hawaii's Self-Supply Program Fundamentally Reshape the State's Solar and Battery Markets? Smart Electric Power Alliance. Accessed November 2016.

Trabish, Herman K. 2016. "Inside the Decision: California Regulators Preserve Retail Rate Net Metering until 2019." Utility Dive. Accessed October 2016:

http://www.utilitydive.com/news/inside-the-decision-california-regulators-preserveretail-rate-net-meterin/413019/.

Tsanova, T. 2016. "Germany's $6^{\text {th }}$ Solar Auction Sees Prices as Low as EUR 62.6/MWh." SeeNews. Accessed December 2016:

http://renewables.seenews.com/news/germanys-6th-solar-auction-sees-prices-as-low-aseur-62-6-mwh-549913. 
van der Burg, Laurie, and Shelagh Whitley. 2016. Rethinking Power Markets: Capacity Mechanisms and Decarbonisation. London: Overseas Development Institute.

Weimar, M.R., M.E. Mylrea, T. Levin, A. Botterud, A., E. O'Shaughnessy, and L. Bird. 2016. Integrating Renewable Generation into Grid Operations. Richland, WA: Pacific Northwest National Laboratory. PNNL- 25331.

http://www.pnnl.gov/main/publications/external/technical_reports/PNNL-25331.pdf.

Weiss, Jurgen. 2014. Solar Energy Support in Germany: A Closer Look. The Brattle Group. Accessed September 2016: http://www.seia.org/research-resources/solar-energysupport-germany-closer-look.

Williard, Tom. 2016. "NEM 2.0 Update: What You Should Know.” Sage Renewables. Accessed September 2016: http://www.sagerenew.com/press/nem.

Wirth, Harry. 2016. Recent Facts about Photovoltaics in Germany. Wirth ISE. Accessed September 2016: https://www.ise.fraunhofer.de/en/publications/veroeffentlichungen-pdfdateien-en/studien-und-konzeptpapiere/recent-facts-about-photovoltaics-in-germany.pdf.

Woodman, B, C. and Mitchell. 2011. "Learning From Experience? The Development of the Renewables Obligation in English and Wales 2002-2010." Energy Policy 39: 39143921.

Zhou, H. 2012. "Impacts of Renewables Obligation with Recycling of the Buy-Out Fund." Energy Policy 46: 284-291. 